\title{
Current status and perspectives of genome editing technology for microalgae
}

\author{
Seungjib Jeon ${ }^{1,2}$, Jong-Min Lim³ ${ }^{3}$, Hyung-Gwan Lee ${ }^{4}$, Sung-Eun Shin ${ }^{5}$, Nam Kyu Kang ${ }^{1}$, Youn-II Park ${ }^{6}$, \\ Hee-Mock $\mathrm{Oh}^{4}$, Won-Joong Jeong ${ }^{3}$, Byeong-ryool Jeong ${ }^{1,2^{*}}$ (D) and Yong Keun Chang ${ }^{1,2^{*}}$
}

\begin{abstract}
Genome editing techniques are critical for manipulating genes not only to investigate their functions in biology but also to improve traits for genetic engineering in biotechnology. Genome editing has been greatly facilitated by engineered nucleases, dubbed molecular scissors, including zinc-finger nuclease (ZFN), TAL effector endonuclease (TALEN) and clustered regularly interspaced palindromic sequences (CRISPR)/Cas9. In particular, CRISPR/Cas9 has revolutionized genome editing fields with its simplicity, efficiency and accuracy compared to previous nucleases. CRISPR/Cas9-induced genome editing is being used in numerous organisms including microalgae. Microalgae have been subjected to extensive genetic and biological engineering due to their great potential as sustainable biofuel and chemical feedstocks. However, progress in microalgal engineering is slow mainly due to a lack of a proper transformation toolbox, and the same problem also applies to genome editing techniques. Given these problems, there are a few reports on successful genome editing in microalgae. It is, thus, time to consider the problems and solutions of genome editing in microalgae as well as further applications of this exciting technology for other scientific and engineering purposes.
\end{abstract}

Keywords: Genetic engineering, Microalgae, Genome editing, CRISPR/Cas9, Biofuels, GMO conflicts

\section{Background}

Targeted genome modifications are crucial for genetic analyses and genetic engineering in all aspects of biology and related biotechnological fields. Different from random integration of cloned genes for overexpression, specific alterations of the eukaryotic genome have been great challenges for all biologists and biotechnologists. Gene targeting (GT) was initially developed in recombinogenic lower eukaryotes by introducing a homologous transgene into the cell, and by utilizing homologous recombination (HR), scientists were able to knockout or replace genes of interest [1]. GT has been successfully demonstrated in animals [2, 3] and plants [4]. However, GT in these higher organisms has been very difficult, in part, because they are not recombinogenic [5]. Newly developed

\footnotetext{
*Correspondence: bjeong@kaist.ac.kr; changyk@kaist.ac.kr; ychang@kaist.ac.kr

${ }^{1}$ Advanced Biomass Research and Development Center (ABC), 291 Daehak-ro, Yuseong-gu, Daejeon 34141, Republic of Korea

Full list of author information is available at the end of the article
}

techniques, including genome editing techniques, have bypassed this hurdle by engineered nucleases, dubbed "molecular scissors," and the subsequent repair of DNA strand breaks results in mutations or replacements of the genes of interest [6].

Engineered nucleases include zinc-finger nucleases (ZFNs), transcription activator-like effector nucleases (TALENs), and clustered regularly interspaced palindromic sequences (CRISPR)/CRISPR-associated protein 9 (Cas9) [7]. These three, in particular CRISPR/Cas9, will be described for microalgal genome editing in this review even though there have been other nucleases including meganucleases and group II intron-based targetrons adopted for genome editing in other organisms [8]. These sequence-specific nucleases have enabled researchers to cleave genomic DNA and to obtain mutations of a gene resulting from faulty repair of the cleaved DNA.

Microalgae have emerged as important platforms for the production of biofuels and other biomolecules, and genetic engineering of microalgae is, thus, one of the fastest growing biotechnology fields [9]. In addition to 
overexpression of genes of interest, genome editing is essential for the suppression of genes interfering with the production of target molecules. However, progress in this field has been hampered by multiple layers of difficulties inherent to microalgae. This review will describe what has been achieved in microalgal genome editing and examine in detail the problems associated with microalgal genome editing and suggest possible solutions. Genome editing has many applications that have been shown in other organisms, and the possibility of these applications in microalgae will also be evaluated. Because the overexpression of genes shares the same technical problems, we will also include a brief description of microalgal transformation technology.

\section{Introduction to genetic engineering}

Genetic engineering, by definition, requires the delivery of genetic material to the genome resulting in genetic modifications. Since reports of successful transfection of animal cells with isolated viral DNAs in the early 1970s $[10,11]$, it took more than 10 years to achieve the transformation of plants using Agrobacteria that are capable of transforming plants in nature [12]. As usual, transformation of the model microalga Chlamydomonas came much later in the late 1980s [13, 14]. The long delay in achieving microalgae transformation was not simply due to a smaller microalgal community but also to technical problems inherent to microalgae. The same delay was seen for genome editing techniques in microalgae. As pointed out lately, successful genome editing should be based on solid transformation techniques for an organism [15]. We, thus, summarize the historical perspectives of plant and microalgal transformation, which can provide clues to genome editing in microalgae.

Transformation of plants lagged behind animals probably due to the presence of the protective cell wall, and initial attempts of a workaround with protoplasts did not provide much success [16]. Instead, plant geneticists developed alternative techniques using the natural transformation machinery of Agrobacteria, which circumvented the removal of the cell wall [12]. In addition to Agrobacteria, particle bombardment also gained popularity, which can avoid the host range limitations of Agrobacteria [17]. Later on, the removal of the plant cell wall improved, and transformation of protoplasts via polyethylene glycol (PEG) or electroporation was also established in plants $[18,19]$.

Transformation of the model microalga Chlamydomonas reinhardtii was achieved by the transformation techniques used for plants, which was done for nuclear [13, 14] and chloroplast genomes [20]. Later, transformation by glass bead agitation was uniquely developed for $C$. reinhardtii, where protoplast cells were agitated vigorously with glass beads [21]. These pioneering works led to the development of the transformation toolbox in Chlamydomonas and other microalgae summarized in Table 1. In general, delivery of genetic material in microalgae is considered much less efficient compared to that of plants. On the other hand, once transformants are obtained, microalgae are mostly single cells and can be maintained somatically, not requiring the tedious (and recalcitrant in some species) regeneration steps in plants [15].

The development of the transformation toolbox in microalgae, excluding Chlamydomonas, presented another layer of difficulties mainly due to the paucity of selection markers that have been developed for plants and other microbes (Table 1). This is probably caused by their evolutionary divergence, where their cellular machineries have been differentiated so much that existing herbicides and antibiotics cannot be used for selection purposes. This is particularly true for the model "industrial microalgae" Nannochloropsis that are tolerant to most antibiotics and herbicides, which leaves only phleomycin and its derivative Zeocin for selection by the ble gene from Streptoalloteichus hindustanus (Shble) [22, 23]. Exceptionally, N. oceanica CCMP1779 is sensitive to hygromycin that is selectable with aphVII [24]. However, green algae sharing lineages with plants offers more options of selection, including hygromycin and other herbicides and antibiotics, similar to that of plants [25].

Microalgal transformation still suffers from an extremely low transformation efficiency, even compared to plants, which calls for drastically improved transformation techniques. Lately, cell wall removal and PEGmediated protoplast transformation have been reported in Chlorella and Cyanidioschyzon [26-29]. PEG-mediated protoplast transformation in plants achieves a higher transformation efficiency without the concerns of the host range of Agrobacteria or expensive equipment [30]. Chlorella is gaining popularity in many global consortia of algal biofuel production, and it is, thus, interesting to see how this technique develops not only in Chlorella but also in other microalgae. Another technique that can be considered is bacterial conjugation for delivery of episomal vectors into microalgal cells, which is claimed to be more efficient than conventional transformation techniques in diatoms [31]. Optimized techniques of these might provide solutions for the current problems of delivery techniques in microalgae, which may be used for genome editing in microalgae.

Development of the transformation toolboxes also provided opportunities for reverse genetic techniques in microalgae, facilitated by the genomic sequencing of $C$. reinhardtii and other microalgae $[24,32]$. These include RNA interference (RNAi) and artificial microRNAs (amiRNAs), based on the findings that microalgae are capable of RNA silencing by small interfering RNAs 
Table 1 Development of the transformation toolbox in microalgae

\begin{tabular}{|c|c|c|c|c|}
\hline Algal strain & Delivery & Marker & Selection/stable integration/comments & References \\
\hline \multicolumn{5}{|l|}{ Chlamydomonas reinhardtii } \\
\hline C. reinhardtii (arg7-) & Particle bombardment & $A R G 7$ & $\begin{array}{l}\text { Growth in arginine free medium/southern blot/correlation of } \\
\text { the genetic and molecular maps of the ARG7 locus }\end{array}$ & {$[14]$} \\
\hline C. reinhardtii (nit1-305) & Particle bombardment & NIT1 & $\begin{array}{l}\text { Growth in the presence of nitrate/southern blot/complemen- } \\
\text { tation with NR deficient mutants }\end{array}$ & {$[153]$} \\
\hline $\begin{array}{l}\text { C. reinhardtii } \\
\text { Fud44 (OEE1-) }\end{array}$ & Particle bombardment & OEE1 & $\begin{array}{l}\text { Photoautotrophic growth/southern blot/complementation } \\
\text { with OEE1-deficient mutants }\end{array}$ & {$[154]$} \\
\hline $\begin{array}{l}\text { A54-e18 (ac17 nitl- } \Delta 1 \text { sr1) and } \\
\text { J9 (cw15 nit1-305) }\end{array}$ & Glass beads agitation & $C R Y 1-1$ & $\begin{array}{l}\text { Resistance to emetine/heritable integration and southern } \\
\text { blot/dominant selectable marker gene }\end{array}$ & {$[21]$} \\
\hline C. reinhardtii (nic7-) & Glass beads agitation & nic-7 & $\begin{array}{l}\text { Resistance to 3-acetylpyridine/southern blot/dominant } \\
\text { selectable marker gene }\end{array}$ & {$[155]$} \\
\hline $\begin{array}{l}\text { C. reinhardtii } \\
363\left(\arg 7-8 \mathrm{cw}_{\mathrm{d}}\right)\end{array}$ & Glass beads agitation & Shble & $\begin{array}{l}\text { Resistance to phleomycin/southern and western blots/first } \\
\text { inheritable expression of a foreign gene in C. reinhardtii }\end{array}$ & {$[22]$} \\
\hline $\begin{array}{l}\text { C. reinhardtii } \\
\text { CC }-124\end{array}$ & Particle bombardment & $\operatorname{aad} A$ & $\begin{array}{l}\text { Resistance to spectinomycin/southern, northern and western } \\
\text { blots/analyses of mRNA expression and stability of aadA }\end{array}$ & {$[156]$} \\
\hline $\begin{array}{l}\text { C. reinhardtii } \\
302(\mathrm{cw} 15 \text { arg7-8) and } A \\
\quad(\mathrm{cw} 15 \text { arg7) }\end{array}$ & Glass beads agitation & aphVIII & $\begin{array}{l}\text { Resistance to paromomycin/southern, northern and western } \\
\text { blots/expression of the aphVIII in C. reinhardtii in combi- } \\
\text { nation with different promoters from rbcS2, hsp70A and } \\
\text { chlamyopsin }\end{array}$ & {$[157]$} \\
\hline $\begin{array}{l}\text { C. reinhardtii } \\
302 \text { cw } 15 \text { arg } 2 \text { and } C C-124\end{array}$ & Glass beads agitation & $a p h V I I$ & $\begin{array}{l}\text { Resistance to hygromycin B/RT-PCR and southern blot/sec- } \\
\text { ond heterologous marker }\end{array}$ & {$[158]$} \\
\hline $\begin{array}{l}\text { C. reinhardtii } \\
\text { CC- } 125, C C-425 \text { and } C w_{d}-A R G\end{array}$ & $\begin{array}{l}\text { Glass beads and elec- } \\
\text { troporation }\end{array}$ & $A L S$ & $\begin{array}{l}\text { Resistance to SMM/southern blot/strong promoter from } \\
\text { RbcS2 for proper expression of ALS }\end{array}$ & {$[159]$} \\
\hline \multicolumn{5}{|l|}{ Chlorella } \\
\hline C. sorokiniana (NR-UV9-5) & Particle bombardment & NIT1 & $\begin{array}{l}\text { Growth in the presence of nitrate/southern blot and RNase } \\
\text { protection assay/rescue of nitrate reductase deficient } C \text {. } \\
\text { sorokiniana mutant }\end{array}$ & {$[40]$} \\
\hline C.vulgaris & Electroporation & hph & $\begin{array}{l}\text { Resistance to hygromycin B/southern blot/dominant selecta- } \\
\text { ble marker gene }\end{array}$ & {$[160]$} \\
\hline $\begin{array}{l}\text { C. vulgaris } \\
\text { C-27 } \\
\text { C. sorokiniana, ATCC- } 22521\end{array}$ & $\begin{array}{l}\text { PEG-mediated transfor- } \\
\text { mation }\end{array}$ & $\mathrm{NeO}^{r}$ & $\begin{array}{l}\text { Resistance to G418 (geneticin)/unstable integration/produc- } \\
\text { tion of human growth hormone }\end{array}$ & {$[27]$} \\
\hline C. ellipsoids KMCC C-20 & $\begin{array}{l}\text { PEG-mediated transfor- } \\
\text { mation }\end{array}$ & Shble & $\begin{array}{l}\text { Resistance to phleomycin/southern and western blots/pro- } \\
\text { duction of flounder growth hormone for feed }\end{array}$ & {$[29]$} \\
\hline C.vulgaris & Electroporation & CAT & $\begin{array}{l}\text { Resistance to chloramphenicol/PCR/heterologous promoter } \\
\text { of NR from diatom }\end{array}$ & {$[161]$} \\
\hline C. zofingiensis ATCC 30412 & $\begin{array}{l}\text { Particle bombardment } \\
\text { and electroporation }\end{array}$ & PDS-L516F & $\begin{array}{l}\text { Resistance to norflurazon/PCR and southern blot/increased } \\
\text { production of carotenoids }\end{array}$ & {$[162]$} \\
\hline C. ellipsoidea & Electroporation & Npt & $\begin{array}{l}\text { Resistance to G418/PCR, RT-PCR and southern blot/heterolo- } \\
\text { gous expression of GmDof4 from soybean for increased } \\
\text { lipid }\end{array}$ & {$[163]$} \\
\hline C. vulgaris CBS 15-2075 & PEG-mediated & Nptll & Resistance to G418/southern blot/expression of EGFP & {$[26]$} \\
\hline \multicolumn{5}{|l|}{ Phaeodactylum tricornutum } \\
\hline $\begin{array}{l}\text { P. tricornutum } \\
\text { Strain } 646\end{array}$ & Particle bombardment & Sh ble & $\begin{array}{l}\text { Resistance to zeocin/southern, northern and western blots/ } \\
\text { transformation toolbox for P. tricornutum }\end{array}$ & {$[164]$} \\
\hline $\begin{array}{l}\text { P. tricornutum } \\
\text { Strain } 646\end{array}$ & Particle bombardment & NptII & $\begin{array}{l}\text { Resistance to neomycin/PCR and western blot/transforma- } \\
\text { tion toolbox for P. tricornutum }\end{array}$ & {$[165]$} \\
\hline $\begin{array}{l}\text { P. tricornutum } \\
\text { CCMP632 }\end{array}$ & Particle bombardment & Shble & $\begin{array}{l}\text { Resistance to phleomycin/PCR, RT-PCR, southern and western } \\
\text { blots/RNA silencing by anti-sense or inverted repeats }\end{array}$ & {$[166]$} \\
\hline $\begin{array}{l}\text { P. tricornutum } \\
\text { UTEX } 646\end{array}$ & Particle bombardment & Shble & $\begin{array}{l}\text { Resistance to zeocin/none/increased DHA contents by heter- } \\
\text { ologous } \triangle 5 \text {-elongase }\end{array}$ & {$[167]$} \\
\hline \multicolumn{5}{|l|}{ Nannochloropsis } \\
\hline N. oceanica W2J3B & Electroporation & Shble & $\begin{array}{l}\text { Resistance to zeocin/PCR/gene targeting of nitrate reductase } \\
\text { and nitrite reductase genes }\end{array}$ & {$[116]$} \\
\hline $\begin{array}{l}\text { N. oceanica } \\
\text { CCMP1779 }\end{array}$ & Electroporation & aphVII & $\begin{array}{l}\text { Resistance to hygromycin B/southern blot/sequencing } \\
\text { genomic DNA and functional annotation in } \mathrm{N} \text {. oceanica }\end{array}$ & {$[24]$} \\
\hline
\end{tabular}


Table 1 continued

\begin{tabular}{|c|c|c|c|c|}
\hline Algal strain & Delivery & Marker & Selection/stable integration/comments & References \\
\hline N. gaditana CCMP526 & Electroporation & Sh ble & $\begin{array}{l}\text { Resistance to zeocin/PCR and southern blot/transformation } \\
\text { toolbox for N. gaditana }\end{array}$ & [168] \\
\hline N. salina CCMP 1776 & Particle bombardment & Shble & $\begin{array}{l}\text { Resistance to zeocin/PCR and western blot/stable expression } \\
\text { of foreign genes }\end{array}$ & [169] \\
\hline N. salina CCMP 1776 & Particle bombardment & Sh ble & $\begin{array}{l}\text { Resistance to zeocin/PCR, RT-PCR, southern and western } \\
\text { blots/overexpression of NsbHLH2 for increased lipid } \\
\text { productivity }\end{array}$ & [23] \\
\hline \multicolumn{5}{|l|}{ Dunaliella } \\
\hline D. salina & Electroporation & CAT & $\begin{array}{l}\text { Resistance to chloramphenicol/PCR, RT-PCR, southern, north- } \\
\text { ern and western blots/stable expression of foreign genes }\end{array}$ & [170] \\
\hline D. salina & Electroporation & Sh ble & $\begin{array}{l}\text { Resistance to zeocin/PCR, RT-PCR and southern blot/transfor- } \\
\text { mation toolbox for D. salina }\end{array}$ & [171] \\
\hline D. viridis B14 (NIA1-) & Electroporation & NIA1 & $\begin{array}{l}\text { Growth in the presence of nitrate salt/RT-PCR and southern } \\
\text { blot/complementation with NR deficient mutants }\end{array}$ & [172] \\
\hline D. salina & Electroporation & CAT & $\begin{array}{l}\text { Resistance to chloramphenicol/PCR and RT-PCR/RNA silenc- } \\
\text { ing by RNAi in D. salina }\end{array}$ & [173] \\
\hline D. salina $19 / 18$ & Particle bombardment & CAT & $\begin{array}{l}\text { Resistance to chloramphenicol/PCR and southern blot/ } \\
\text { increased total lipid content by } 12 \% \text { through endogenous } \\
\text { expression of } M E / A C C D\end{array}$ & [174] \\
\hline \multicolumn{5}{|l|}{ Haematococcus pluvialis } \\
\hline $\begin{array}{l}\text { H. pluvialis } \\
\text { NIES-144 }\end{array}$ & Particle bombardment & PDS-L504R & $\begin{array}{l}\text { Resistance to norflurazon/southern, northern and western } \\
\text { blots/production of astaxanthin }\end{array}$ & [175] \\
\hline $\begin{array}{l}\text { H. pluvialis } \\
\text { SAG 19-a }\end{array}$ & $\begin{array}{l}\text { Agrobacterium-mediated } \\
\text { transformation }\end{array}$ & hph & $\begin{array}{l}\text { Resistance to hygromycin/PCR and southern blot/transforma- } \\
\text { tion toolbox for H. pluvialis }\end{array}$ & [176] \\
\hline $\begin{array}{l}\text { H. pluvialis } \\
\text { SAG 34-1a }\end{array}$ & $\begin{array}{l}\text { Agrobacterium-mediated } \\
\text { transformation }\end{array}$ & hph & $\begin{array}{l}\text { Resistance to hygromycin/PCR and southern blot/overex- } \\
\text { pression of bkt for increased carotenoids and astaxanthin } \\
\text { production }\end{array}$ & [177] \\
\hline
\end{tabular}

aadA, aminoglycoside 3'-adenyltransferase; ALS, acetolactate synthase; aphVII, aminoglycoside phosphotransferase; aphVIII, aminoglycoside 3'-phosphotransferase; $A R G 7$, argininosuccinate lyase; $A C C D$, acetyl CoA carboxylase; bkt, beta carotene ketolase; $C A T$, chloramphenicol acetyltransferase; $C R Y 1-1$, ribosomal protein S14; DHA, docosahexaenoic acid; $h p h$, hygromycin phosphotransferase; ME, malic enzyme; Neo', neomycin phosphotransferase; nic-7, quinolinate synthetase; NIT1, NIA1, nitrate reductase; Npt, neomycin phosphotransferase; OEE1, oxygen-evolving enhancer protein 1; PDS, phytoene desaturase; Sh ble, phleomycin binding protein; SMM, sulfometuron methyl

(siRNA) and microRNAs (miRNAs) in C. reinhardtii and in other microalgae [24, 33-38]. In addition to the RNA-based knockdown techniques, gene targeting via HR was also introduced in Chlamydomonas and Chlorella $[39,40]$; however, these results were not reproducible probably due to the non-recombinogenic nature of microalgae. Similar difficulties were also observed in most of higher eukaryotes including animals and plants [2-4] because gene targeting was originally developed in recombinogenic yeasts [1]. Difficulties and/or inefficiencies of the above reverse genetic techniques called for a more efficient and precise modification of DNA, which led to genome editing, also known as genome engineering, using engineered nucleases. This review will further discuss genome editing, mainly focusing on microalgae, including difficulties and possible solutions.

\section{Genome editing using engineered nucleases}

Genome editing uses recombinant nucleases engineered to recognize and cleave specific sequences in the genome, resulting in double strand breaks (DSBs). DSBs are repaired mostly by a homology-independent and errorprone DNA repair mechanism, called non-homologous end joining (NHEJ), resulting in mutations at the cleavage site [41-46]. Nucleases include ZFN, TALEN and CRISPR/Cas9 as summarized in Fig. 1a, and Table 2 lists representative cases of genome editing in plants and animals and all known cases of microalgal genome editing. Unfortunately, attempts of genome editing in microalgae have had limited success with only a handful of reports. Other endonucleases have been used for genome editing in other organisms, including meganucleases and group II intron-based targetrons as summarized in Fig. 1b [8, $47,48]$. It would be interesting to find out how these nucleases work in microalgae.

ZFN and TALEN appeared as an alternative to gene targeting via $H R$ and have been used for targeted modification of genomes [49-52]. They are fusion proteins of the restriction enzyme FokI [53] and their respective DNA binding proteins of zinc finger [54-58] and transcription activator-like effector (TALE) [59], summarized in Fig. 1a. The resulting DSBs induced by FokI are repaired mostly by 
a

ZFN

TALEN

CRISPR/Cas 9

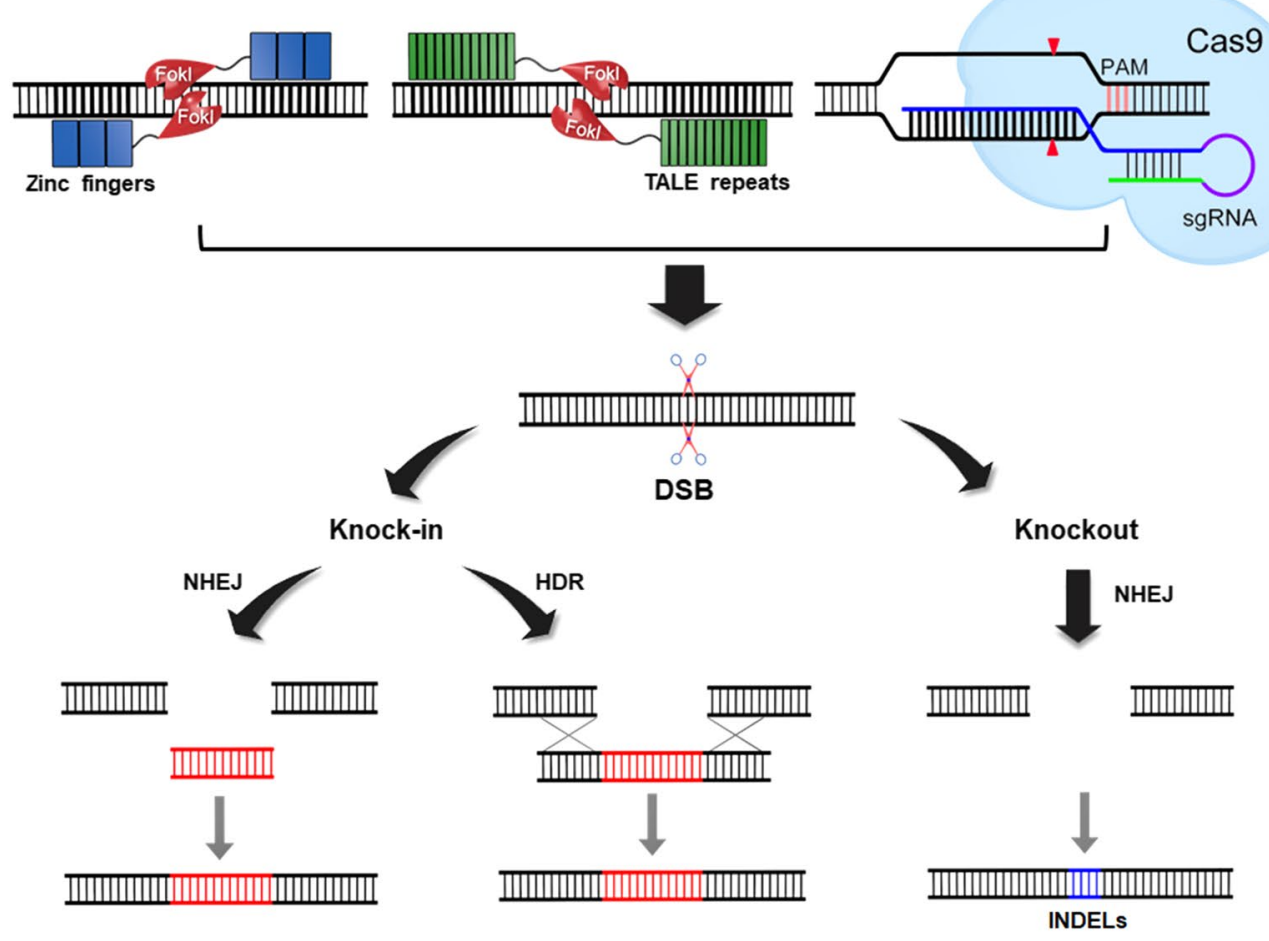

b

Meganucleases

Targetron
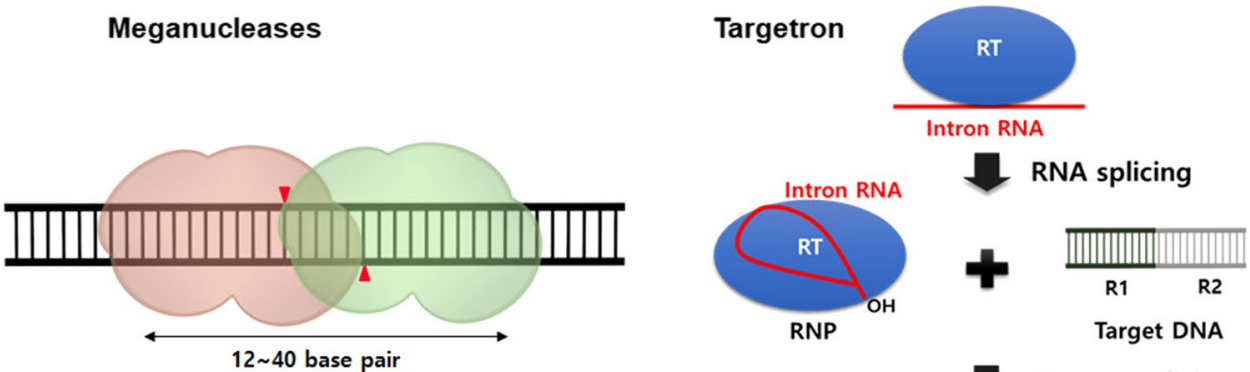

\begin{tabular}{ccc}
\hline & Source & Recognition sequence \\
\hline I-Scel & $\begin{array}{c}\text { Saccharomyces } \\
\text { cerevisiae } \\
\text { Chlamydomonas } \\
\text { reinhardtii } \\
\text { I-Crel }\end{array}$ & TAGGGATAACAGGGTAAT \\
I-Ceul & $\begin{array}{c}\text { CAAmydomas } \\
\text { eugametos } \\
\text { Desulfurococcus } \\
\text { mobilis }\end{array}$ & TAACTATAACGGTCCTAAGGTAGCGA \\
I-Dmol & GCCTGCCGGGTAAGTTCCGGCGC \\
\hline
\end{tabular}

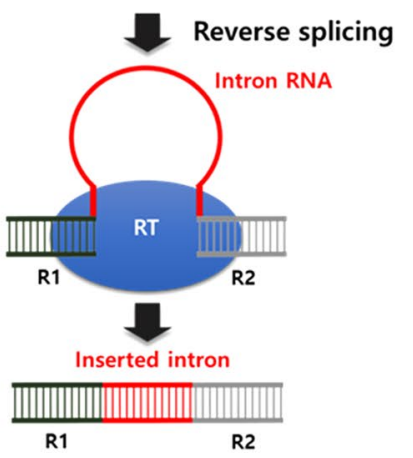

c

\begin{tabular}{|c|c|}
\hline $\begin{array}{c}\text { ZFN } \\
\text { (Kim et al., 1996) }\end{array}$ & $\begin{array}{l}\text { TALEN } \\
\text { (Christian et al., 2010) }\end{array}$ \\
\hline Until 2000 & Until 2010 \\
\hline
\end{tabular}

CRISPR/Cas 9

(Cong et al., 2013, Mali et al., 2013)

2013

ZFN in

Chlamydomonas

(Sizova et al., 2013)
TALEN in Diatom (Daboussi et al., 2014)

2014

CRISPR/Cas9 in

Chlamydomonas (Jiang et al., 2014)
Cas9 RNPs in

Chlamydomonas (Shin et al., 2016, Baek et al., 2016)

2016

CRISPR/Cas9 in

Diatoms

(Nymark et al., 2016, Wang et al., 2016) 
(See figure on previous page.)

Fig. 1 Summary of genome editing techniques using engineered nucleases. The first two nucleases are made by a fusion of a zinc-finger protein and TALE to the restriction enzyme Fokl, producing ZFN and TALEN, respectively (a). In contrast, Cas9 contains nuclease domains for the cleavage of DNA and RNA binding domains for the guide RNAs, which offer simplicity and better accuracy compared to the predecessors. All three nucleases produce DSBs, and INDELs can be produced via error-prone DNA repair NHEJ. When donor DNAs (red) are provided, knock-in events can be produced via either NHEJ or HDR. Other types of nucleases were summarized $(\mathbf{b})$, including meganucleases and targetrons. Timeline of the major nucleases and their use in genome editing were summarized in c. Their first reports are shown in shades, and those of microalgal genome editing are shown in solid boxes

the error-prone repair mechanism, NHEJ, in most eukaryotes, and mutations can be created at the cleavage sites in the form of small insertions or deletions (INDELs). A donor DNA can be included in the mutagenesis process and can be inserted at the DSB site via NHEJ or HR, which is called a knock-in [60]. A knock-in can be used for more efficient disruption of the target gene or stable expression of a gene at a specific location of the genome [45, 61], which will be discussed in more detail.

CRISPR/Cas9 has gained much attention not only from biologists who are actually working on it but also from the social media including the economic, legal, and industrial sectors [62], which is reflected by the heated legal battles for the patent of CRISPR/Cas9 [63, 64]. This unprecedented attention is mainly due to its excellent potential as the next generation genome editing technique. CRISPR/Cas9 is simple, accurate and efficient compared to other editing techniques [7, 61]. In addition, recombinant Cas 9 protein can be assembled with single guide RNA (sgRNA) and delivered as ribonucleoproteins (Cas9 RNPs) into the cells $[60,65]$. Delivery of Cas9 RNPs can minimize off-targeting and thus cytotoxicity, and avoid the hassles of cloning markers and sgRNAs. More importantly, the Cas 9 nuclease activity can be assessed prior to the lengthy transformation process [60, $65,66]$. Cas9 RNPs, in contrast to vector-driven expression of Cas9 and sgRNAs, may also avoid conflicts from genetically modified organisms (GMOs) depending on the different legal systems [67-69]. Given the advantage of CRISPR/Cas9, this review will focus on it as the choice of genome editing techniques in microalgae. Lately many variations of different classes and types of CRISPR/ Cas9 have been reported [70], and thus, CRISPR will be reserved for the general term for all or any variations.

\section{Biology and application of CRISPR}

The CRISPR locus was first identified as short direct repeats interspaced with short sequences in E. coli [71] and later in other bacteria and even in mitochondria and giant viruses, as summarized in Fig. 2a [72, 73]. The CRISPR systems are adaptive immune systems that provide sequence-specific protection against invading viruses or conjugative plasmids [70, 74-76]. It should be noted that there is another type of immunity in bacteria called restriction-modification systems [75, 77], for which the restriction enzymes revolutionized molecular biology resulting in the Nobel Prize in 1978. CRISPR is also revolutionizing all aspects of biology and biotechnology and may be nominated for a Noble Prize [78].

The CRISPR immunity is divided into three stages (Fig. 2b): spacer acquisition (or adaptation), CRISPR RNA (crRNA) biogenesis, and interference stages. During the spacer acquisition stage, a target DNA sequence, known as a protospacer, is excised and inserted at the $5^{\prime}$ end of the CRISPR array producing a new spacer. The subsequent crRNA biogenesis includes transcription and processing of the CRISPR array into mature crRNAs. At the final interference stage, crRNAs guide the effector complex to the target site and cleave the DNA producing DSBs in the re-invading viruses. There are excellent reviews on the biology of CRISPR [70, 74, 76]. This review will focus on the effectors including endonucleases because these nucleases are used for genome editing [79].

The CRISPR systems can be classified into two classes and six types, summarized in Fig. 2a. Class 1 CRISPR systems contain effectors composed of multi-subunit proteins, while those of class 2 contain a single effector with multi-domain such as Cas9 or Cpf1. Class 1 is divided into types I, III and IV, and class 2 includes types II, V and VI, for which the types were numbered based on their order of discovery $[74,80]$. The CRISPR systems are very diverse, and Fig. 2 depicts only a representative composition of genes at the CRISPR loci. It is estimated that CRISPR is present in about $50 \%$ of bacteria and $\sim 90 \%$ of archaea [80]. For the purpose of technological applications, class 2 effector nucleases are mainly used due to their convenience in cloning and delivery into host cells. Class 2 nucleases are also diverse in their structural and functional aspects, and this diversity heralds a new age of genome editing that can be customized for individual research projects [74].

\section{Use of CRISPR for genome editing}

Since the initial finding of the mysterious repeats of the CRISPR array in E. coli in 1987 and in many other bacteria in 2000 [71, 72, 81], CRISPR/Cas9 has been shown 
Table 2 Genome editing in microalgae and other organisms

\begin{tabular}{|c|c|c|c|c|}
\hline Organism & Delivery/nuclease & Gene/marker & Comments & References \\
\hline \multicolumn{5}{|l|}{ Animals } \\
\hline CHO-S cells (11619-012) & $\begin{array}{l}\text { Lipofectamine } 2000 \text { transfection } \\
\text { ZFN }\end{array}$ & DHFR & $\begin{array}{l}\text { Identification of biallelic knockouts after a } \\
\text { single transient ZFN treatment }\end{array}$ & {$[57]$} \\
\hline $\begin{array}{l}\text { SKOV3 cells } \\
\text { ATCC }\end{array}$ & $\begin{array}{l}\text { FuGENE HD transfection reagent } \\
\text { TALEN }\end{array}$ & EGFP and DsRed & Development of TALENs in mammalian cells & {$[59]$} \\
\hline $\begin{array}{l}\text { Mouse cells } \\
\text { NIH3T3 }\end{array}$ & $\begin{array}{l}\text { Microinjection or Lipofectamine } \\
2000 \\
\text { CRISPR/Cas9 }\end{array}$ & EGFP and $A p o E$ & $\begin{array}{l}\text { Improvement of bi-allelic modification by } \\
\text { dual sgRNAs }\end{array}$ & {$[178]$} \\
\hline $\begin{array}{l}\text { Human cell lines } \\
\text { MCF-7, NSCLC and A549 }\end{array}$ & $\begin{array}{l}\text { Lipofectamine } 2000 \text { transfection } \\
\text { CRISPR/Cas9 }\end{array}$ & $\begin{array}{l}\text { Mitochondrial GTPase } \\
\text { Mitofusin-2/GFP }\end{array}$ & Identification of role MFN2 in human cells & {$[179]$} \\
\hline $\begin{array}{l}\text { H9 human ES cells and other } \\
\text { cell lines }\end{array}$ & $\begin{array}{l}\text { Electroporation } \\
\text { CRISPR/Cas9 }\end{array}$ & CCR5 gene & Genome editing Cas9 RNPs & {$[65]$} \\
\hline Mouse zygotes & $\begin{array}{l}\text { Electroporation } \\
\text { CRISPR/Cas9 }\end{array}$ & Tyrosinase gene & Genome editing Cas9 RNPs & {$[180]$} \\
\hline $\begin{array}{l}\text { Zebrafish (Danio rerio) strain } \\
\qquad A B\end{array}$ & $\begin{array}{l}\text { Microinjection into embryos } \\
\text { CRISPR/Cas9 }\end{array}$ & akt2 gene & Functional role of akt2 gene in zebrafish & {$[181]$} \\
\hline \multicolumn{5}{|l|}{ Plants } \\
\hline Nicotiana tabacum (tobacco) & $\begin{array}{l}\text { Protoplast transformation } \\
\text { TALEN }\end{array}$ & ALS gene/YFP gene & $\begin{array}{l}\text { Successful targeted gene replacement with } \\
\text { TALENs }\end{array}$ & {$[51]$} \\
\hline Arabidopsis thaliana & $\begin{array}{l}\text { Agrobacterium-mediated trans- } \\
\text { formation } \\
\text { CRISPR/Cas9 }\end{array}$ & $\begin{array}{l}\text { ADH1, TT4, RTEL1 } \\
\text { gene/bar gene }\end{array}$ & $\begin{array}{l}\text { Genome editing using CRISPR/Cas9-based } \\
\text { nucleases and nickases }\end{array}$ & {$[101]$} \\
\hline Arabidopsis thaliana & $\begin{array}{l}\text { Agrobacterium-mediated trans- } \\
\text { formation } \\
\text { CRISPR/Cas9 }\end{array}$ & GFP gene & $\begin{array}{l}\text { Stable inheritance of Cas9/sgRNA-generated } \\
\text { mutant genes in T2 and T3 progeny }\end{array}$ & {$[182]$} \\
\hline Camelina sativa & $\begin{array}{l}\text { Agrobacterium-mediated trans- } \\
\text { formation } \\
\text { CRISPR/Cas9 }\end{array}$ & FAD2 gene & $\begin{array}{l}\text { Induced mutations caused change in fatty } \\
\text { acid composition }\end{array}$ & {$[183]$} \\
\hline Maize Hi-line & $\begin{array}{l}\text { Particle bombardment } \\
\text { CRISPR/Cas } 9\end{array}$ & $\begin{array}{l}\text { LIG, ALS2, MS26 and } \\
\text { MS45/MOPAT-DSREB }\end{array}$ & Genome editing Cas9 RNPs & {$[184]$} \\
\hline Wheat embryos & $\begin{array}{l}\text { Particle bombardment } \\
\text { CRISPR/Cas } 9\end{array}$ & TaGW2 gene & Genome editing Cas9 RNPs & {$[185]$} \\
\hline \multicolumn{5}{|l|}{ Cyanobacteria } \\
\hline $\begin{array}{l}\text { Synechococcus elongatus } \\
\text { UTEX } 2973\end{array}$ & $\begin{array}{l}\text { Conjugation } \\
\text { CRISPR/Cas9 }\end{array}$ & $n b \mid A$ & $\begin{array}{l}\text { Genome editing using CRISPR/Cas9-based } \\
\text { nucleases }\end{array}$ & {$[186]$} \\
\hline $\begin{array}{l}\text { Synechococcus elongatus } \\
\text { PCC } 7942\end{array}$ & $\begin{array}{l}\text { Conjugation } \\
\text { CRISPR/Cas9 }\end{array}$ & glgc/Gm gene & $\begin{array}{l}\text { Increase of succinate } \\
\text { Production }\end{array}$ & {$[187]$} \\
\hline Synechococcus UTEX 2973 & $\begin{array}{l}\text { Conjugation } \\
\text { CRISPR/Cpf1 }\end{array}$ & psba1, nbla & $\begin{array}{l}\text { Genome editing using CRISPR/Cpf1-based } \\
\text { nucleases }\end{array}$ & [188] \\
\hline $\begin{array}{l}\text { Synechocystis } 6803 \\
\text { Anabaena } 7120\end{array}$ & $\begin{array}{l}\text { Conjugation } \\
\text { CRISPR/Cpf1 }\end{array}$ & $\begin{array}{l}\text { nblA } \\
\text { nifH }\end{array}$ & $\begin{array}{l}\text { Genome editing using CRISPR/Cpf1-based } \\
\text { nucleases }\end{array}$ & {$[188]$} \\
\hline \multicolumn{5}{|l|}{ Microalgae } \\
\hline C. strain CC-4350 & $\begin{array}{l}\text { Glass beads } \\
\text { ZFN }\end{array}$ & $\begin{array}{l}\text { COP3 gene/aphVIII } \\
\text { gene }\end{array}$ & Targeted gene knockout induced by ZFN & {$[58]$} \\
\hline P. tricornutum CCMP2561 & $\begin{array}{l}\text { Bombardment } \\
\text { TALEN }\end{array}$ & UGPase/NAT gene & Increase in triacylglycerol accumulation & {$[91]$} \\
\hline C. reinhardtii CC 503 & $\begin{array}{l}\text { Electroporation } \\
\text { CRISPR/Cas9 }\end{array}$ & FKB12 gene & $\begin{array}{l}\text { First application of CRISPR/Cas9 in micro- } \\
\text { algae }\end{array}$ & {$[111]$} \\
\hline P. tricornutum CCMP2561 & $\begin{array}{l}\text { Bombardment } \\
\text { CRISPR/Cas9 }\end{array}$ & CpSRP54 gene/Shble & First application of CRISPR/Cas9 in diatoms & [189] \\
\hline $\begin{array}{l}\text { C. reinhardtii } \\
\text { CC }-124\end{array}$ & $\begin{array}{l}\text { Electroporation } \\
\text { CRISPR/Cas9 }\end{array}$ & $\begin{array}{l}\text { MAA7, CPSRP43 and } \\
\text { ChIM }\end{array}$ & $\begin{array}{l}\text { Targeted gene knockout and knock-in via } \\
\text { NHEJ in Chlamydomonas }\end{array}$ & {$[60]$} \\
\hline $\begin{array}{l}\text { C. reinhardtii } \\
\text { CC }-4349\end{array}$ & $\begin{array}{l}\text { Electroporation } \\
\text { CRISPR/Cas9 }\end{array}$ & ZEP and CPFTSY & Production of two-gene knockout mutant & {$[112]$} \\
\hline $\begin{array}{l}\text { C. reinhardtii } \\
\text { CC }-400\end{array}$ & $\begin{array}{l}\text { Glass beads } \\
\text { CRISPR/dCas } 9\end{array}$ & PEPC 1 and $R F P$ & CRISPRi in Chlamydomonas & {$[104]$} \\
\hline
\end{tabular}


Table 2 continued

\begin{tabular}{llll}
\hline Organism & Delivery/nuclease & Gene/marker & Comments \\
\hline N. oceanica IMET1 & Electroporation & Nitrate reductase & Targeted gene knockout in Nannochloropsis \\
& CRISPR/Cas9 & gene/HygR & Knockout and attenuation of ZnCys in Nan- \\
N. gaditana CCMP1894 & Electroporation & ZnCys TF & nochloropsis
\end{tabular}

$A D H 1$, alcohol dehydrogenase 1; akt2, AKT serine/threonine-protein kinases 2; ALS, acetolactate synthase; aphVIII, aminoglycoside 3'-phosphotransferase; ApoE, apolipoprotein E; bar, herbicide bialaphos; BSD, blasticidin S deaminase; CCR5, C-C motif chemokine receptor 5; ChIM, Mg-protoporphyrin IX S-adenosyl methionine $O$-methyl transferase; COP3, light-gated proton channel rhodopsin; CpFTSY, signal recognition particle receptor protein, chloroplast; $C p S R P 43$, chloroplast signal recognition particle 43; CpSRP54, chloroplast signal recognition particle 54; DHFR, dihydrofolate reductase; DsRed, red fluorescent protein; EGFP, green fluorescent protein; $F A D 2$, fatty acid desaturase 2; FKB12, peptidyl-prolyl cis-trans isomerase; glgc, glucose-1-phosphate adenylyl transferase; Gm ${ }^{\mathrm{R}}$, gentamycin-resistance gene; HygR, hygromycin resistance; $L I G$, liguleless $1 ; M A A 7$, beta subunit of tryptophan synthase; MFN2, mitochondrial GTPase mitofusin-2; MS26 and MS45, male fertility genes; NAT, $N$-acetyl transferase; $n b l A$, phycobilisome degradation protein; $n i f H$, nitrogenase reductase; $P E P C$, phosphoenolpyruvate carboxylase; $P s b A 1$, D1 protein of photosystem II; RFP, red fluorescent protein; RTEL1, regulator of telomere length 1; TaGW2, gene related to grain development; TT4, transparent testa 4; UGPase, UDPglucose pyrophosphorylase; YFP, yellow fluorescent protein; ZEP, zeaxanthin epoxidase

to target DNA specifically in vitro resulting in DSBs [82, 83]. This led to the first reports of genome editing in eukaryotic cells in 2013 [84, 85], and then, an explosive number of reports followed [79] (Table 2).

The advantages of the CRISPR system for genome editing reside in the effector nucleases, for which the nucleases do not require the tedious and labor-intensive cloning of DNA binding domains for targeting specificity. In contrast to the predecessor nucleases ZFN and TALEN, the DNA specificity of CRISPR nucleases is provided by a guide RNA composed of crRNA and trans-activating crRNA (tracrRNA), which were further simplified by the sgRNA [7]. This simple design and preparation of CRISPR enables multiplexed mutagenesis by simply adding up sgRNAs [86, 87]. In addition, CRISPR nucleases appear to be more efficient and more precise compared to predecessors [88].

Another advantage of CRISPR is the diverse nucleases which can be customized for individual needs. Cas9 from Streptococcus pyogenes (SpCas9) was initially used for CRISPR-mediated genome editing in animal cells [82, 83]. Lately, nucleases including CRISPR from Prevotella and Francisella 1 (Cpf1) and CRISPR from Campylobacter jejuni (CjCas9) have been introduced for genome editing with improved efficiency and specificity $[41,89,90]$. New class 2 CRISPR systems are being reported, and the number is increasing [74], and different types of nucleases will offer customization of the editing technique for individual research projects.

Best of all, CRISPR appears to be most efficient in microalgal genome editing based on the number of papers reported so far, even though it debuted last in the genome editing field (Table 2). ZFN and TALEN have been used for mutagenesis of Chlamydomonas and a diatom, respectively $[58,91]$, and to the best of our knowledge, there have not been any follow-up reports. Fortunately, CRISPR is gaining a strong foothold in microalgal genome editing, which may provide the possibility of practical and efficient genome editing in microalgae.

However, CRISPR technology still has some limitations, which requires improvements for proper use in genome editing. CRISPR-induced mutations occur randomly depending on the repair of DSBs mostly via NHEJ [92, 93]. Currently precision genome engineering is emerging for better management of mutagenesis, including gene replacement, multiple cleavage and base correction [46], some of which will be further described in "Applications of the CRISPR system" section. Off-targeting can still be an issue for medical and agricultural purposes, even though CRISPR is considered as the most accurate genome editing technique [94]. Fortunately, CRISPR offers a variety of nucleases with improved versatility and/or fidelity, which can also provide optional PAM sequences [41, 89, 90, 95]. These improvements will benefit both biology and biotechnology fields, particularly for microalgal community.

\section{Technical aspects of CRISPR-mediated genome editing}

A key to successful genome editing is efficient delivery of genetic materials, and it has been the main bottleneck in transformation of microalgae. In general, the cell wall is considered as the most significant barrier for the introduction of macromolecules into plant cells [16]. To avoid this problem, the cell wall is removed, and the resulting protoplasts are subjected to PEG-mediated transfection, which appears to be very effective without the need for expensive supplies and equipment $[18,30$, 96]. With the proper removal of the cell wall, this technique can result in a transfection efficiency of up to $70 \%$ in cassava mesophyll protoplasts [97], which may offer an opportunity to improve microalgal transformation. In fact, as summarized in Table 1, there have been a few reports on PEG-mediated transformation of microalgae including Chlorella [26, 27, 29] and Cyanidioschyzon [28]. These attempts did not result in a greatly improved 


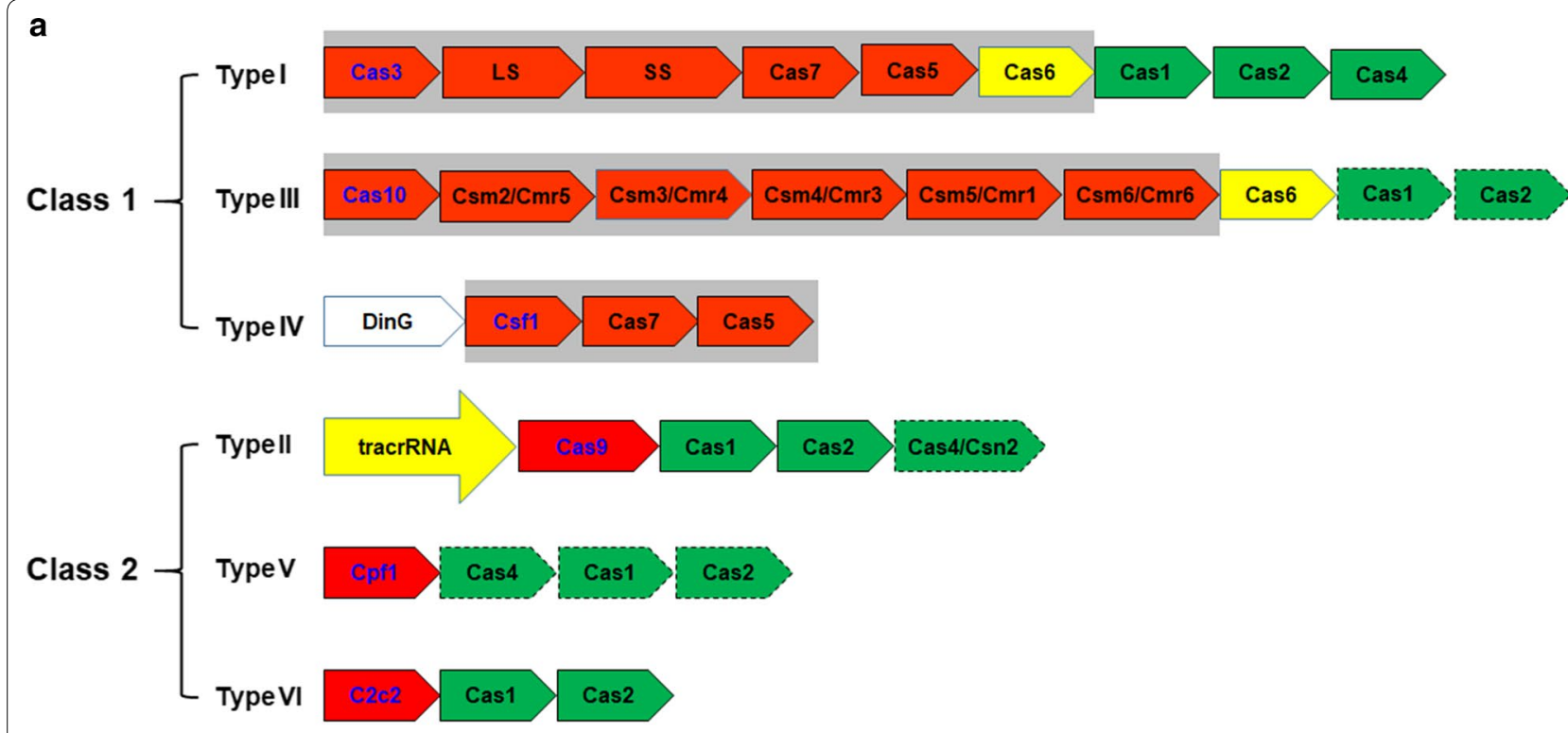

b

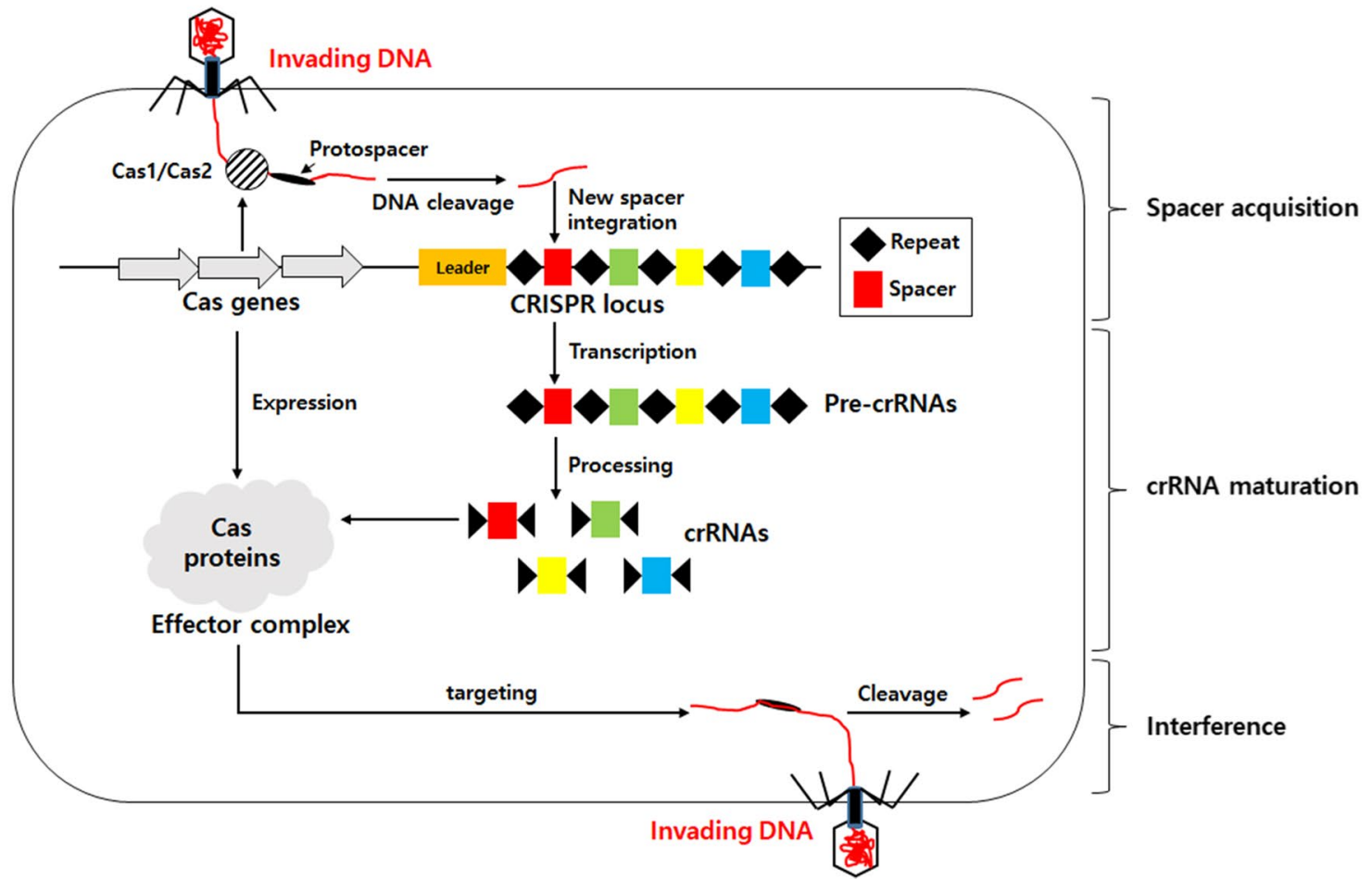

Fig. 2 Different subtypes of the CRISPR systems (a) and their biological mechanisms of immunity against invading viruses (b). Genes involved in interference are shown in the red boxes and those involved in crRNA biogenesis and adaption in the yellow boxes and green boxes, respectively, mainly based on $[74,80]$. The signature gene of each types is indicated by blue letters, and the complex of multiple effector proteins is indicated by gray boxes. Dispensable genes are indicated by dashed lines. LS, large subunit; SS, small subunit

transformation efficiency; however, this technique can be improved by complete and/or efficient removal of the cell wall, which may also improve genome editing in microalgae.
Next, successful genome editing in microalgae can be achieved by proper use of the CRISPR nucleases, particularly with the class 2 , which are single peptides containing all the functional domains necessary for 
sequence-specific DNA cleavage [74]. The founding member of such nucleases is SpCas9, and its homologs have been identified in many bacterial strains, and they use two RNA molecules (crRNA and tracrRNA) or one sgRNA for binding to the protospacer, the target sequence on DNA. SpCas9 has the protospacer adjacent motif (PAM) as an additional sequence specificity that provides security minimizing off-target effects. PAM for SpCas9 is mainly NGG but sometimes NAG and is located directly $3^{\prime}$ to the protospacer $[7,79]$.

Cas9 homologs are equipped with two endonuclease domains producing DSBs, namely the RuvC and $\mathrm{HNH}$ domains. These domains are modular enabling individual engineering for different purposes. $\mathrm{RuvC}$ was originally identified as part of the RuvABC operon (for "resistance to UV light") and is the endonuclease involved in the resolution of the Holliday junction during UV repair [98]. The HNH domain (named for the histidine, asparagine and histidine residues critical for the nuclease activity) is found in many endonucleases including restriction enzymes and meganucleases [99]. Both RuvC and $\mathrm{HNH}$ domains are required for producing DSBs. However, their catalytic sites can be modified to produce a nickase by making an individual mutation of either D10A or H840A, respectively $[79,100]$. Such Cas9 nickases are not efficient for inducing mutations but can be used for enhanced knock-in of expression cassettes via HR [101]. In addition, both catalytic sites can be mutated to produce the dead Cas9 (dCas9), and this can be used for variants of CRISPR/Cas9 techniques including CRISPR interference (CRISPRi), where dCas9 is used as a sequence-specific DNA binding protein leading to interference of transcription of the target gene [102-104].

The CRISPR system also offers different types of nucleases, such as Cpf1 and $\mathrm{C} 2 \mathrm{c} 1$, which is considered the biggest advantage compared to other genome editing techniques [74]. Cpf1 was initially identified as a type V CRISPR effector from Prevotella and Francisella, which shows endonucleolytic activities different from Cas9. The differences include a T-rich PAM site and staggered cleavage of DNA located $3^{\prime}$ to PAM [95]. Cpf1 from Acidaminococcus sp. (AsCpf1) and Lachnospiraceae bacterium (LbCpf1) have been used for genome editing in animals and plants $[66,89,95]$. These Cpf1s do not require tracrRNA, which offers simpler preparation of the guide RNA. In addition, it appears to be more efficient and accurate than Cas9 [66, 89] and thus has emerged as the next generation nuclease for genome editing. Additional type $\mathrm{V}$ nucleases, but less studied, include $\mathrm{C} 2 \mathrm{c} 1$ and $\mathrm{C} 2 \mathrm{c} 3$. These type $\mathrm{V}$ effectors are further classified as subtype V-B and V-C, while Cpf1 belongs to the V-A subtype [74]. These subtypes are characterized by different domain structures, which can be used for customized genome editing purposes.

Interestingly, there is another type of CRISPR system containing endonucleases that cleave RNA targets instead of DNA. These belong to the type VI, and the sequence-specific RNases include C2c2 and many others $[74,105]$. The type VI CRISPR system is reminiscent of the eukaryotic RNA silencing mechanism involving the RNA-induced silencing complex (RISC), in which Argonaute (AGO) and Dicer carry out guide RNA (i.e., siRNA)-based sequence-specific identification and cleavage of the target RNA, respectively [106-108]. However, C2c2 carries both functions [109] revealing another bacterial ingenuity of simplicity, in contrast to the bulky, complex and elaborate eukaryotic counterparts. RNAi in eukaryotic systems is not very reliable in the suppression of gene expression particularly in microalgae [110], and the type VI CRISPR systems may provide a better alternative.

Different from any gnome editing techniques, the CRISPR system enables the delivery of preassembled Cas9 or Cpf1 RNP with the cognate guide RNAs in vitro $[65,89]$. Compared to vector-driven expression of the nucleases and guide RNAs, the RNP system is simple and convenient without the need for the laborious and time-consuming cloning process and thus obtains results faster. There are other benefits of the RNP approach including the pre-test of the nuclease activity in vitro. There was a correlation between in vitro and in vivo activities of SpCas9 in Chlamydomonas for different target sites in the same gene [60]. In addition, RNP delivery can minimize off-target effects and possible toxicity from the continuous expression of a nuclease [60, 65, 111]. It does not introduce any artificial DNA including markers and heterologous genes and may avoid GMO conflicts [67]. Best of all, it has been successful in the recalcitrant model algae Chlamydomonas [60,112]. This may provide interesting opportunities to deal with the difficulties in microalgal genome editing.

Considering the difficulties in delivering genetic materials into microalgal cells, microalgal genome editing is gaining momentum with the CRISPR/Cas9 systems summarized in Table 2. In case of vector-based Cas9 expression in microalgae, codon usage can be optimized for better expression of Cas9 in microalgae [60, 111-114]. This achievement is in part due to the efficiency and simplicity of the CRISPR systems $[60,112]$. Another reason can be due to the fact that many microalgae are haploids, enabling the selection of knocked-out clones without the need to make homozygotes. Green algae, including chlorophytes and charophytes, are considered to have a haplontic life cycle in which their genomes are haploids during vegetative growth [115], and this may be true in 
other microalgae including Nannochloropsis [116] and Guillardia [117]. On the other hand, haploids do not allow the knockout of essential genes, which should be considered before making a gene list for potential knockouts. In this case, one can consider the CRISPR knockdown approaches such as CRISPRi and attenuation of gene expression by targeting UTRs that will be described in more detail $[118,119]$.

\section{Applications of the CRISPR system}

The simplicity of the CRISPR systems has led to a sudden increase in variant technologies, which was difficult with previous techniques of genome editing or any reverse genetic techniques. First, the Cas9 nuclease can be easily manipulated to create nickases or dCas9, and these variants can be used for additional genome manipulation including knock-in and CRISPRi [7, 60, 102]. Second, multiple sites can be targeted simultaneously by simply adding guide RNAs, for which two sites can be targeted to obtain a chromosomal deletion, inversion or translocation [7]. The numbers can be increased to target multiple genes at the same time [86] or even to create a barcoded CRISPR mutant library [87]. It should also be noted that anti-CRISPRs have been identified in bacteriophages as an arms race against their hosts $[120,121]$, which provides an interesting possibility that they can be used in genome editing, such as a conditional knockout. There is a long list of applications for the CRISPR systems [119, $122,123]$, and some of these that are relevant or applicable to microalgae will be described in this review.

\section{dCas9 for CRISPRi and manipulation of gene expression}

Cas9 contains well defined endonuclease domains that can be modified to create a nickase or even dCas9, and these mutants can also be used for new exciting techniques. In particular, dCas9 can bind to the target site without cleaving DNA, and this can interfere with cellular processes including transcription. This CRISPRi technique has been shown in bacteria and even in Chlamydomonas [102, 104, 119, 124]. In bacteria, dCas9 interferes with the expression of target gene(s) by providing steric hindrance to RNA polymerase or transcription factors, depending on the location of target sites [102, 124]. In Chlamydomonas, CRISPRi is shown to knockdown the expression of phosphoenolpyruvate carboxylase (PEPC) [104], albeit less effective possibly due to the difference between prokaryotic and eukaryotic transcription mechanisms, where eukaryotic transcription is more tolerant to DNA binding proteins including chromatin.

dCas9 can also be repurposed for other functions by fusion of domains involved in transcriptional activation (CRISPRa), repression (CRISPRi), and epigenetic regulation (Fig. 3). It should be noted that CRISPRi is used for simple interference without any fused proteins [102, 124] and for active interruption with repressor domains [119], which may be resolved in the future. For CRISPRa, the multiple repeats of the herpes simplex VP16 activation domain (VP64) and the nuclear factor- $\mathrm{kB}$ transactivating subunit activation domain (p65AD) have commonly been used as activator domains in eukaryote systems [125127]. These subunits are fused to the $\mathrm{N}$ or $\mathrm{C}$ terminus of dCas 9 as a single or multiple units. After it is shown that having more activators improve the activation efficiency, several units including different activator domains can be added. For example, the 'SunTag' array consists of 10 copies of a small peptide epitope each linked with VP64 and sfGFP by scFV [128]. As another example, the synergistic tripartite activation method (VPR) uses a tandem fusion of three transcription activators, VP64, p65 and Rta [129]. The synergistic activation mediator (SAM) is fused to VP64, and two MS2 RNA aptamers added to the tetraloop and second stem-loop of the sgRNA recruit p65Ad and heat shock factor1 (HSF1) through MCP [130, 131].

Repressors that have been used in CRISPRi include MAX-interacting protein 1 (MXI1) from yeast, Krüppelassociated box (KRAB) domain of Kox1, the CS domain of HP1 $\alpha$, the WPRW domain of Hes1, or four concatenated $\mathrm{mSin} 3$ domains (SID4X) which are fused either to the amino or carboxyl terminus [125, 132, 133]. However, it appears that this field has some room for improvements. Epigenetic regulation is critical for proper expression of genes, which can be achieved by histone and DNA modifications. The Lys-specific histone demethylase 1 (LSD1) fusion protein, the catalytic core of histone acetyltransferase (p300), or DNMT3A, a DNA methyltransferase, has been tested with dCas9 [134-136]. These can be used as epigenome editing tools to reveal interactions between the epigenome and regulatory elements and their epigenetic mechanism of gene expression [137, 138] not only in higher eukaryotes but also in microalgae.

\section{Knock-ins with CRISPR}

CRISPR can also be used for a knock-in and replacement of a gene(s), if given a donor DNA(s) (Fig. 1). During the repair process of DNA breaks caused by CRISPR nucleases, the donor DNA can be integrated at the cleavage site via HDR or NHEJ. The donor DNA without any inserted expression cassette can also be used for replacement of a gene via HDR [7, 139]. Given the homologous sequences flanking the transgene, single-stranded donor DNAs can be integrated at the cleavage site of nucleases including TALEN [140, 141]. Alternatively, Cas9 nickase (D10A) can also enhance knock-in or gene replacement in plants [101]. Interestingly, a knock-in can also occur through NHEJ (Fig. 1a), where no homologous sequences are present in the transgene. NHEJ-mediated 


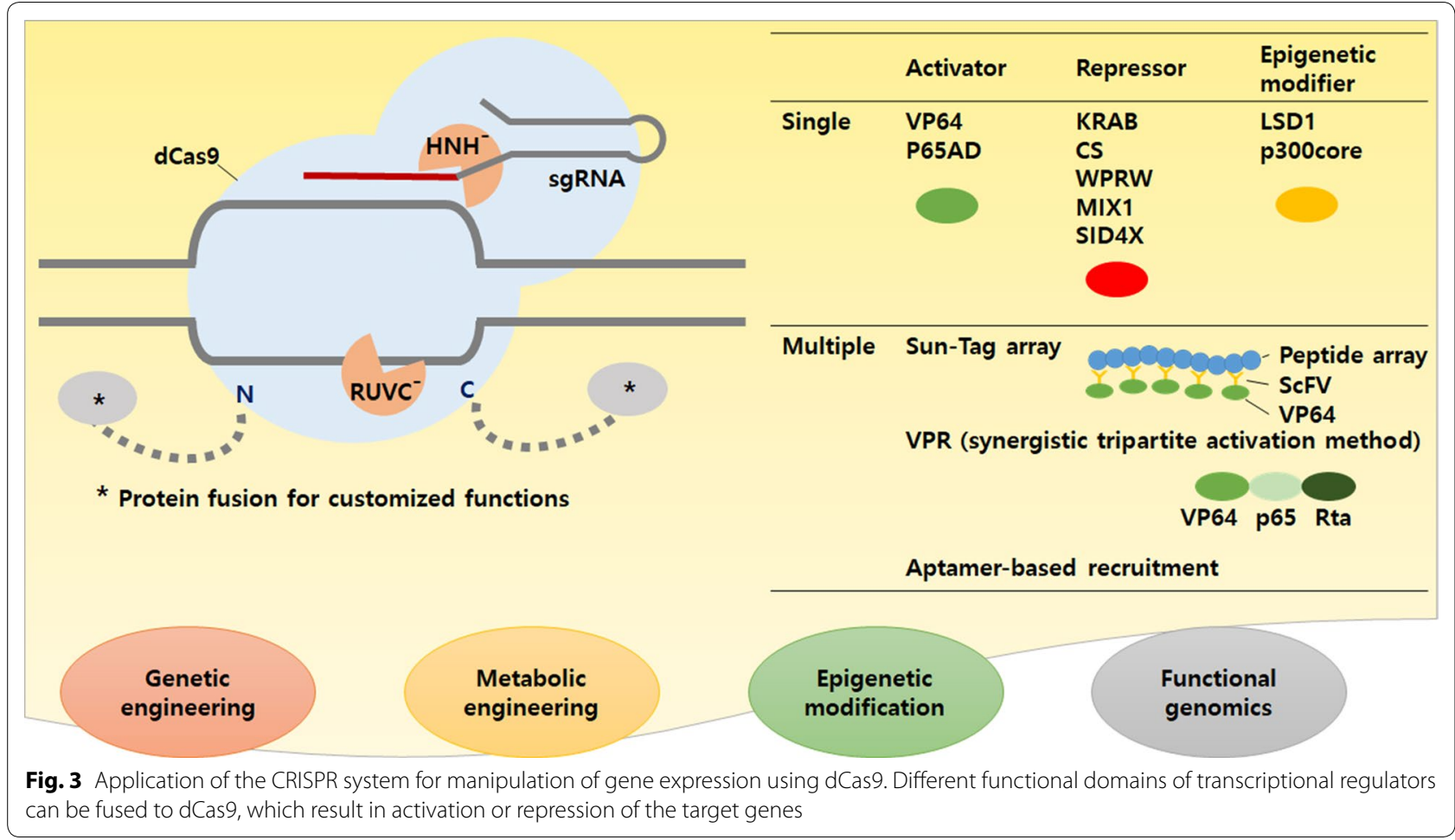

knock-in events have been reported in zebrafish and Chlamydomonas [60, 142].

Knock-in events can be used in targeted integration of transgenes at certain locations on the genome. Random integration of transgenes suffers from position effects and transgene silencing [143, 144]. Such detrimental effects are also known in microalgae including Chlamydomonas $[33,34,145-147]$ and can influence the stable expression of transgenes. These problems can be solved in part by integrating transgenes at transcriptionally favorable locations on the genome. Actually, such "safe-harboring" has been shown; the knock-in of transgenes at transcriptionally active sites, e.g., near the rDNA cluster, increases the expression of transgenes [46, 148, 149]. Currently, functional genomic data including RNA-Seq and epigenomics mapping of histone modifications can offer candidates of transcriptionally active locations. These locations can be targeted for the integration of expression cassettes. In microalgae, fortunately, cloning of the flanking homologous sequences may be not necessary because the knock-in via NHEJ can occur in Chlamydomonas and Nannochloropsis $[60,114]$.

\section{Perspectives of genome editing in microalgae}

Microalgae and CRISPR are relatively new additions to biotechnology fields, which are expected to contribute to biomaterial production and genome editing techniques, respectively. Combination of the two quintessential components is potentially the key to solve the environmental problems associated with usage of fossil fuels. Such example has been reported recently, where CRISPRinduced knockout or attenuation of a regulatory gene can increase lipid accumulation in industrial microalgae Nannochloropsis [114].

Different from previous editing techniques, CRISPR allows systemic, albeit labor-intensive, screening of knockout mutations due to its simplicity and convenience $[113,114]$. This is reflected by the number of reports, in which ZFN and TALEN-induced mutagenesis for only one for each techniques since 2013 [58, 91]. However, successful genome editing with CRISPR alone has been documented three times in 2016 as summarized in Table 2. This success heralds new and improved genome editing field in microalgae, which attracts great interests of academic and industrial biology and biotechnology.

Even though microalgae are difficult in genetic manipulation, their biological characteristics offer advantages. They are single cells, and mostly contain haploid genomes for their vegetative cells $[115-117,150]$. This leads to convenient knockout without the necessity of regeneration, which is considered a main bottleneck in plants [15]. In addition, being haploid, microalgae do not have to go through another generation for homozygotes. On the other hand, complete knockout of an essential gene is 
not possible, in which attenuation should be considered. For example, attenuation can be achieved by targeting outside of coding sequence such as untranslated regions or by CRISPRi $[114,119]$.

\section{Problems and possible solutions with CRISPR application in microalgae}

Microalgae are still difficult to manipulate genes possibly due to their multitude of problems. Firstly, it is hard to deliver genetic materials into the cells, probably because they have unique cell wall and surface structures that reflect their complex taxonomic lineages [151]. This diversity hinders development of standardized protocols for transformation. To avoid such problems, one can remove the cell wall and employ protoplast transformation, which has been demonstrated for a few microalgae including Chlorella as summarized in Table 1 [26, 27, 29]. Protoplasts are in general easier to transform, which may improve efficiencies of not only transformation but also genome editing. Secondly, microalgae may have very efficient silencing systems against introduced genetic materials including DNA and RNA at the transcriptional and post-transcriptional levels. Such silencing systems have been reported for the model algal Chlamydomonas $[33,145]$, and are expected to exist in other microalgae [34]. Temporary knockdown of one of the silencing components may improve transformation efficiency [34]. Permanent mutations of silencing components are not recommended, because they are also involved in genome stability [145].

Cas9 RNP appears to be more efficient than vectordriven Cas9 in Chlamydomonas [60, 111, 112], and is advantageous if heterogeneous genetic material should not be introduced, particularly in areas where GMOs are prohibited. However, high quality non-toxic recombinant Cas9 protein is not easy to prepare or is expensive to purchase from a company. However, for research purposes, a stable line of Cas9 or equivalent nucleases can be constructed for efficient gene editing. For example, the Cas9 Editor line has been successfully employed to produce 18 mutations in Nannochloropsis [114].

Precision genome editing technologies require precise mutagenesis without producing off-targeting events, which has not been well established in microalgae. Such precision is crucial for certain applications of CRISPR particularly for gene therapy in human, and is well established in animals and plants [152]. Fidelity of genome editing can be improved by Cas9 RNP in animal cells $[65,66]$, and Shin et al. reported no off-targeting events in Chlamydomonas using Cas9 RNP [60]. Other than the latter, off-targeting has not been examined in microalgae, where such efforts should improve safety and consistency of genome editing in microalgae.

\section{Conclusions}

Genome editing is essential for obtaining mutations of target genes enabled by recombinant nucleases with sequence specificity. The latest nucleases found in the CRISPR systems are far better than the predecessors in terms of their simplicity, accuracy and efficiency. This improved CRISPR technology can be used in the correction of mutations, replacement of genes, and targeted integration of overexpression cassettes. It can also be used for many other purposes including attenuation of gene expression, removal of transgenic markers, etc., and the list is getting longer. The microalgal community is catching up with this new and exciting technology but is lagging behind the main stream technical developments in animals and plants. We need to first solve the fundamental problems in microalgae, which is the inefficient delivery of genetic materials into the cell. Given such a tremendous barrier, many more papers have been reported with CRISPR compared to the previous techniques, which may herald a new age of genome editing in microalgae.

\section{Abbreviations \\ amiRNAs: artificial microRNAs; Cas9 RNPs: Cas9/gRNA ribonucleoproteins; Cpf1: CRISPR from Prevotella and Francisella 1; CRISPR/Cas9: clustered regularly interspaced palindromic sequences/CRISPR-associated protein 9; CRISPRa: CRISPR activation; CRISPRi: CRISPR interference; crRNA: CRISPR RNA; dCas9: dead Cas9; DSBs: double strand breaks; GMO: genetically modified organism; GT: gene targeting; HDR: homology-dependent recombination; HR: homolo- gous recombination; INDELs: insertions or deletions; miRNAs: microRNAs; NHEJ: non-homologous end joining; PAM: protospacer adjacent motif; PEG: polyethylene glycol; RNAi: RNA interference; sgRNA: single guide RNA; SiRNA: small interfering RNAs; SpCas9: Cas9 from Streptococcus pyogenes; TALEN: TAL effector endonuclease; tracrRNA: trans-activating crRNA; VP64: VP16 activation domain; ZFN: zinc-finger nuclease.}

\section{Authors' contributions}

YKC, B-rJ, H-MO, W-JJ and Y-IP conceived of and outlined this review; J-ML, Y-IP and W-JJ contributed to "Introduction to genetic engineering" section and "Genome editing using engineered nucleases" section; $\mathrm{H}-\mathrm{GL}$ and $\mathrm{H}-\mathrm{MO}$ contributed to "Applications of the CRISPR system" section; SJ, S-ES, KNK and B-rJ contributed to "Background" section, "Genome editing using engineered nucleases" section, "Biology and application of CRISPR" section, and "Perspectives of genome editing in microalgae"; YKC, SJ and B-rJ organized and drafted the whole manuscript. All authors read and approved the final manuscript.

\section{Author details}

${ }^{1}$ Advanced Biomass Research and Development Center (ABC), 291 Daehak-ro, Yuseong-gu, Daejeon 34141, Republic of Korea. ${ }^{2}$ Department of Chemical and Biomolecular Engineering, Korea Advanced Institute of Science and Technology (KAIST), 291 Daehak-ro, Yuseong-gu, Daejeon 34141, Republic of Korea. ${ }^{3}$ Plant Systems Engineering Research Center, Korea Research Institute of Bioscience and Biotechnology (KRIBB), 125 Gwahak-ro, Yuseong-gu, Daejeon 34141, Republic of Korea. ${ }^{4}$ Cell Factory Research Center, Korea Research Institute of Bioscience and Biotechnology (KRIBB), 125 Gwahak-ro, Yuseong-gu, Daejeon 34141, Republic of Korea. ${ }^{5}$ LG Chem, 188 Munji-ro, Yuseong-gu, Daejeon 34122, Republic of Korea. ${ }^{6}$ Department of Biological Sciences, Chungnam National University, Daejeon 34134, Republic of Korea.

\section{Acknowledgements}

This work was supported by the Advanced Biomass R\&D Center (ABC) of Global Frontier Project funded by the Ministry of Science, ICT and Future 
Planning (ABC-2011-0031350, ABC-2010-0029728, ABC-2011-0031343, ABC2010-0029723 and NRF-2015M3A6A2065747).

\section{Competing interests}

The authors declare that they have no competing interests.

\section{Availability of data and materials}

Not applicable.

\section{Consent for publication}

Not applicable.

\section{Ethics approval and consent to participate}

None.

\section{Publisher's Note}

Springer Nature remains neutral with regard to jurisdictional claims in published maps and institutional affiliations.

Received: 4 August 2017 Accepted: 4 November 2017

Published online: 14 November 2017

\section{References}

1. Hinnen A, Hicks JB, Fink GR. Transformation of yeast. Proc Natl Acad Sci USA. 1978;75(4):1929-33.

2. Doetschman T, Gregg RG, Maeda N, Hooper ML, Melton DW, Thompson $\mathrm{S}$, Smithies $\mathrm{O}$. Targetted correction of a mutant HPRT gene in mouse embryonic stem cells. Nature. 1987;330(6148):576-8.

3. Thomas KR, Capecchi MR. Site-directed mutagenesis by gene targeting in mouse embryo-derived stem cells. Cell. 1987;51(3):503-12.

4. Lee KY, Lund P, Lowe K, Dunsmuir P. Homologous recombination in plant cells after Agrobacterium-mediated transformation. Plant Cell. 1990;2(5):415-25.

5. Puchta H, Fauser F. Gene targeting in plants: 25 years later. Int J Dev Biol. 2013;57(6-8):629-37.

6. Tan W, Proudfoot C, Lillico SG, Whitelaw CB. Gene targeting, genome editing: from Dolly to editors. Transgenic Res. 2016;25(3):273-87.

7. Kim H, Kim JS. A guide to genome engineering with programmable nucleases. Nat Rev Genet. 2014;15(5):321-34.

8. Guha TK, Wai A, Hausner G. Programmable genome editing tools and their regulation for efficient genome engineering. Comput Struct Biotechnol J. 2017:15:146-60.

9. Jeon S, Jeong B-r, Chang YK. Chemicals and fuels from microalgae. In: Lee SY, editor. Consequences of microbial interactions with hydrocarbons, oils, and lipids: production of fuels and chemicals., Handbook of hydrocarbon and lipid microbiologyCham: Springer International Publishing; 2017. p. 1-21.

10. Nicolson MO, McAllister RM. Infectivity of human adenovirus-1 DNA Virology. 1972;48(1):14-21.

11. Graham FL, van der Eb AJ. A new technique for the assay of infectivity of human adenovirus 5 DNA. Virology. 1973;52(2):456-67.

12. Tepfer D. Transformation of several species of higher plants by Agrobacterium rhizogenes: sexual transmission of the transformed genotype and phenotype. Cell. 1984;37(3):959-67.

13. Fernández E, Schnell R, Ranum LP, Hussey SC, Silflow CD, Lefebvre PA. Isolation and characterization of the nitrate reductase structural gene of Chlamydomonas reinhardtii. Proc Natl Acad Sci USA. 1989;86(17):6449-53.

14. Debuchy R, Purton S, Rochaix JD. The argininosuccinate lyase gene of Chlamydomonas reinhardtii: an important tool for nuclear transformation and for correlating the genetic and molecular maps of the ARG7 locus. EMBO J. 1989:8(10):2803-9.

15. Altpeter F, Springer NM, Bartley LE, Blechl AE, Brutnell TP, Citovsky V, Conrad LJ, Gelvin SB, Jackson DP, Kausch AP, et al. Advancing crop transformation in the era of genome editing. Plant Cell. 2016;28(7):1510-20.
16. Finer JJ. Plant nuclear transformation. In: Kempken F, Jung C, editors. Genetic modification of plants: agriculture, horticulture and forestry. Berlin: Springer; 2010. p. 3-21.

17. Klein TM, Wolf ED, Wu R, Sanford JC. High-velocity microprojectiles for delivering nucleic-acids into living cells. Nature. 1987:327(6117):70-3.

18. Lazzeri PA, Brettschneider R, Lührs R, Lörz H. Stable transformation of barley via PEG-induced direct DNA uptake into protoplasts. Theor Appl Genet. 1991;81(4):437-44

19. Shimamoto K, Terada R, Izawa T, Fujimoto H. Fertile transgenic rice plants regenerated from transformed protoplasts. Nature. 1989;338(6212):274-6.

20. Boynton JE, Gillham NW, Harris EH, Hosler JP, Johnson AM, Jones AR, Randolph-Anderson BL, Robertson D, Klein TM, Shark KB, et al. Chloroplast transformation in Chlamydomonas with high velocity microprojectiles. Science. 1988;240(4858):1534-8.

21. Nelson JA, Savereide PB, Lefebvre PA. The CRY1 gene in Chlamydomonas reinhardtii: structure and use as a dominant selectable marker for nuclear transformation. Mol Cell Biol. 1994;14(6):4011-9.

22. Stevens DR, Rochaix JD, Purton S. The bacterial phleomycin resistance gene ble as a dominant selectable marker in Chlamydomonas. Mol Gen Genet. 1996;251(1):23-30.

23. Kang NK, Jeon S, Kwon S, Koh HG, Shin SE, Lee B, Choi GG, Yang JW Jeong B-r, Chang YK. Effects of overexpression of a bHLH transcription factor on biomass and lipid production in Nannochloropsis salina. Biotechnol Biofuels. 2015;8:200.

24. Vieler A, Wu G, Tsai CH, Bullard B, Cornish AJ, Harvey C, Reca IB, Thornburg C, Achawanantakun R, Buehl CJ, et al. Genome, functional gene annotation, and nuclear transformation of the heterokont oleaginous alga Nannochloropsis oceanica CCMP1779. PLoS Genet. 2012;8(11):e1003064

25. León R, Fernández E. Nuclear transformation of eukaryotic microalgae: historical overview, achievements and problems. Adv Exp Med Biol. 2007;616:1-11.

26. Yang B, Liu J, Liu B, Sun PP, Ma XN, Jiang Y, Wei D, Chen F. Development of a stable genetic system for Chlorella vulgaris-A promising green alga for $\mathrm{CO}_{2}$ biomitigation. Algal Res. 2015;12:134-41.

27. Hawkins RL, Nakamura M. Expression of human growth hormone by the eukaryotic alga, Chlorella. Curr Microbiol. 1999;38(6):335-41.

28. Ohnuma M, Misumi O, Fujiwara T, Watanabe S, Tanaka K, Kuroiwa T. Transient gene suppression in a red alga, Cyanidioschyzon merolae 10D. Protoplasma. 2009;236(1-4):107-12.

29. Kim DH, Kim YT, Cho J, Bae JH, Hur SB, Hwang I, Choi TJ Stable integration and functional expression of flounder growth hormone gene in transformed microalga, Chlorella ellipsoidea. Mar Biotechnol (NY). 2002;4(1):63-73

30. Masani MY, Noll GA, Parveez GK, Sambanthamurthi R, Prüfer D. Efficient transformation of oil palm protoplasts by PEG-mediated transfection and DNA microinjection. PLoS ONE. 2014;9(5):e96831.

31. Karas BJ, Diner RE, Lefebvre SC, McQuaid J, Phillips AP, Noddings CM, Brunson JK, Valas RE, Deerinck TJ, Jablanovic J, et al. Designer diatom episomes delivered by bacterial conjugation. Nat Commun. 2015;6:6925.

32. Merchant SS, Prochnik SE, Vallon O, Harris EH, Karpowicz SJ, Witman GB, Terry A, Salamov A, Fritz-Laylin LK, Marechal-Drouard L, et al. The Chlamydomonas genome reveals the evolution of key animal and plant functions. Science. 2007;318(5848):245-50.

33. Wu-Scharf D, Jeong B-r, Zhang C, Cerutti H. Transgene and transposon silencing in Chlamydomonas reinhardtii by a DEAH-box RNA helicase. Science. 2000;290(5494):1159-62.

34. Kim EJ, Ma X, Cerutti H. Gene silencing in microalgae: mechanisms and biological roles. Bioresour Technol. 2015;184:23-32.

35. Cerutti $\mathrm{H}$, Johnson AM, Gillham NW, Boynton JE. Epigenetic silencing of a foreign gene in nuclear transformants of Chlamydomonas. Plant Cell. 1997:9(6):925-45.

36. Yamasaki T, Kim EJ, Cerutti H, Ohama T. Argonaute3 is a key player in miRNA-mediated target cleavage and translational repression in Chlamydomonas. Plant J. 2016;85(2):258-68.

37. Zhao T, Li G, Mi S, Li S, Hannon GJ, Wang XJ, Qi Y. A complex system of small RNAs in the unicellular green alga Chlamydomonas reinhardtii. Genes Dev. 2007:21(10):1190-203. 
38. Molnár A, Schwach F, Studholme DJ, Thuenemann EC, Baulcombe DC. miRNAs control gene expression in the single-cell alga Chlamydomonas reinhardtii. Nature. 2007;447(7148):1126-9.

39. Nelson JA, Lefebvre PA. Targeted disruption of the NIT8 gene in Chlamydomonas reinhardtii. Mol Cell Biol. 1995;15(10):5762-9.

40. Dawson HN, Burlingame R, Cannons AC. Stable transformation of Chlorella: rescue of nitrate reductase-deficient mutants with the nitrate reductase gene. Curr Microbiol. 1997;35(6):356-62.

41. Zhang K, Raboanatahiry N, Zhu B, Li M. Progress in genome editing technology and its application in plants. Front Plant Sci. 2017;8:177.

42. Wijshake T, Baker DJ, van de Sluis B. Endonucleases: new tools to edit the mouse genome. Biochim Biophys Acta. 2014;1842(10):1942-50.

43. Zaidi SS, Tashkandi M, Mansoor S, Mahfouz MM. Engineering plant immunity: using CRISPR/Cas9 to generate virus resistance. Front Plant Sci. 2016:7:1673.

44. Seol JH, Shim EY, Lee SE. Microhomology-mediated end joining: good, bad and ugly. Mutat Res. 2017. doi:10.1016/j.mrfmmm.2017.07.002.

45. Lieber MR. The mechanism of double-strand DNA break repair by the nonhomologous DNA end-joining pathway. Annu Rev Biochem. 2010;79:181-211.

46. Salsman J, Dellaire G. Precision genome editing in the CRISPR era Biochem Cell Biol. 2017:95(2):187-201.

47. Smith J, Grizot S, Arnould S, Duclert A, Epinat JC, Chames P, Prieto J, Redondo P, Blanco FJ, Bravo J, et al. A combinatorial approach to create artificial homing endonucleases cleaving chosen sequences. Nucleic Acids Res. 2006:34(22):e149.

48. Lambowitz AM, Zimmerly S. Group II introns: mobile ribozymes that invade DNA. Cold Spring Harb Perspect Biol. 2011;3(8):a003616.

49. Gaj T, Gersbach CA, Barbas CF 3rd. ZFN, TALEN, and CRISPR/ Cas-based methods for genome engineering. Trends Biotechnol. 2013;31(7):397-405

50. Bibikova M, Golic M, Golic KG, Carroll D. Targeted chromosomal cleavage and mutagenesis in Drosophila using zinc-finger nucleases. Genetics. 2002;161(3):1169-75.

51. Zhang Y, Zhang F, Li X, Baller JA, Qi Y, Starker CG, Bogdanove AJ, Voytas DF. Transcription activator-like effector nucleases enable efficient plant genome engineering. Plant Physiol. 2013;161(1):20-7.

52. Carlson DF, Tan W, Lillico SG, Stverakova D, Proudfoot C, Christian M, Voytas DF, Long CR, Whitelaw CB, Fahrenkrug SC. Efficient TALENmediated gene knockout in livestock. Proc Natl Acad Sci USA. 2012;109(43):17382-7.

53. Sugisaki H, Kanazawa S. New restriction endonucleases from Flavobacterium okeanokoites (Fokl) and Micrococcus luteus (Mlul). Gene. 1981;16(1-3):73-8.

54. Smith J, Bibikova M, Whitby FG, Reddy AR, Chandrasegaran S, Carroll $D$. Requirements for double-strand cleavage by chimeric restriction enzymes with zinc finger DNA-recognition domains. Nucleic Acids Res. 2000;28(17):3361-9

55. Cathomen T, Joung JK. Zinc-finger nucleases: the next generation emerges. Mol Ther. 2008;16(7):1200-7.

56. Carroll D. Progress and prospects: zinc-finger nucleases as gene therapy agents. Gene Ther. 2008;15(22):1463-8.

57. Santiago Y, Chan E, Liu PQ, Orlando S, Zhang L, Urnov FD, Holmes MC, Guschin D, Waite A, Miller JC, et al. Targeted gene knockout in mammalian cells by using engineered zinc-finger nucleases. Proc Natl Acad Sci USA. 2008;105(15):5809-14.

58. Sizova I, Greiner A, Awasthi M, Kateriya S, Hegemann P. Nuclear gene targeting in Chlamydomonas using engineered zinc-finger nucleases. Plant J. 2013;73(5):873-82.

59. Feng $Y$, Zhang $S$, Huang $X$. A robust TALENs system for highly efficient mammalian genome editing. Sci Rep. 2014;4:3632.

60. Shin SE, Lim JM, Koh HG, Kim EK, Kang NK, Jeon S, Kwon S, Shin WS, Lee B, Hwangbo K, et al. CRISPR/Cas9-induced knockout and knock-in mutations in Chlamydomonas reinhardtii. Sci Rep. 2016:6:27810.

61. Bortesi L, Fischer R. The CRISPR/Cas9 system for plant genome editing and beyond. Biotechnol Adv. 2015;33(1):41-52.

62. Chang K. These foods aren't genetically modified but they are 'edited'. In: The New York Times. Internet: The New York Times; 2017. p. D1.

63. Cohen J. CRISPR patent ruling leaves license holders scrambling. Science. 2017:355(6327):786.
64. Ledford H. Broad Institute wins bitter battle over CRISPR patents. Nature. 2017;542(7642):401.

65. Kim S, Kim D, Cho SW, Kim J, Kim JS. Highly efficient RNA-guided genome editing in human cells via delivery of purified Cas9 ribonucleoproteins. Genome Res. 2014;24(6):1012-9.

66. Kim D, Kim J, Hur JK, Been KW, Yoon SH, Kim JS. Genome-wide analysis reveals specificities of Cpf1 endonucleases in human cells. Nat Biotechnol. 2016;34(8):863-8.

67. Kim J, Kim JS. Bypassing GMO regulations with CRISPR gene editing Nat Biotechnol. 2016;34(10):1014-5.

68. Woo JW, Kim J, Kwon SI, Corvalan C, Cho SW, Kim H, Kim SG, Kim ST, Choe S, Kim JS. DNA-free genome editing in plants with preassembled CRISPR-Cas9 ribonucleoproteins. Nat Biotechnol. 2015;33(11):1162-4.

69. Editorial Nature. Gene editing in legal limbo in Europe. Nature. 2017:542:392

70. Choi KR, Lee SY. CRISPR technologies for bacterial systems: current achievements and future directions. Biotechnol Adv. 2016:34(7):1180-209.

71. Ishino Y, Shinagawa H, Makino K, Amemura M, Nakata A. Nucleotide sequence of the iap gene, responsible for alkaline phosphatase isozyme conversion in Escherichia coli, and identification of the gene product. J Bacteriol. 1987;169(12):5429-33.

72. Mojica FJ, Díez-Villaseñor C, Soria E, Juez G. Biological significance of a family of regularly spaced repeats in the genomes of Archaea, Bacteria and mitochondria. Mol Microbiol. 2000;36(1):244-6.

73. Levasseur A, Bekliz M, Chabriere E, Pontarotti P, La Scola B, Raoult D. MIMIVIRE is a defence system in mimivirus that confers resistance to virophage. Nature. 2016;531(7593):249-52.

74. Shmakov S, Smargon A, Scott D, Cox D, Pyzocha N, Yan W, Abudayyeh OO, Gootenberg JS, Makarova KS, Wolf YI, et al. Diversity and evolution of class 2 CRISPR-Cas systems. Nat Rev Microbiol. 2017:15(3):169-82.

75. Deveau H, Garneau JE, Moineau S. CRISPR/Cas system and its role in phage-bacteria interactions. Annu Rev Microbiol. 2010;64:475-93.

76. Jiang F, Doudna JA. CRISPR-Cas9 structures and mechanisms. Annu Rev Biophys. 2017 (in press).

77. Nathans D, Smith HO. Restriction endonucleases in the analysis and restructuring of DNA molecules. Annu Rev Biochem. 1975;44:273-93.

78. Cohen J. The birth of CRISPR Inc. Science. 2017:355(6326):680-4.

79. Hsu PD, Lander ES, Zhang F. Development and applications of CRISPRCas9 for genome engineering. Cell. 2014;157(6):1262-78.

80. Wright AV, Nunez JK, Doudna JA. Biology and applications of CRISPR systems: harnessing nature's toolbox for genome engineering. Cell. 2016;164(1-2):29-44

81. Mojica FJ, Juez G, Rodriguez-Valera F. Transcription at different salinities of Haloferax mediterranei sequences adjacent to partially modified Pstl sites. Mol Microbiol. 1993:9(3):613-21.

82. Jinek M, Chylinski K, Fonfara I, Hauer M, Doudna JA, Charpentier E. A programmable dual-RNA-guided DNA endonuclease in adaptive bacterial immunity. Science. 2012;337(6096):816-21.

83. Gasiunas G, Barrangou R, Horvath P, Siksnys V. Cas9-crRNA ribonucleoprotein complex mediates specific DNA cleavage for adaptive immunity in bacteria. Proc Natl Acad Sci USA. 2012;109(39):E2579-86.

84. Cong L, Ran FA, Cox D, Lin S, Barretto R, Habib N, Hsu PD, Wu X, Jiang W, Marraffini LA, et al. Multiplex genome engineering using CRISPR/Cas systems. Science. 2013;339(6121):819-23.

85. Mali P, Yang L, Esvelt KM, Aach J, Guell M, DiCarlo JE, Norville JE, Church GM. RNA-guided human genome engineering via Cas9. Science. 2013;339(6121):823-6.

86. Wang $H$, Yang $H$, Shivalila CS, Dawlaty MM, Cheng AW, Zhang F, Jaenisch R. One-step generation of mice carrying mutations in multiple genes by CRISPR/Cas-mediated genome engineering. Cell. 2013;153(4):910-8

87. Wong AS, Choi GC, Cui CH, Pregernig G, Milani P, Adam M, Perli SD, Kazer SW, Gaillard A, Hermann M, et al. Multiplexed barcoded CRISPRCas9 screening enabled by CombiGEM. Proc Natl Acad Sci USA 2016:113(9):2544-9.

88. Peng R, Lin G, Li J. Potential pitfalls of CRISPR/Cas9-mediated genome editing. FEBS J. 2016;283(7):1218-31.

89. Kim H, Kim ST, Ryu J, Kang BC, Kim JS, Kim SG. CRISPR/Cpf1-mediated DNA-free plant genome editing. Nat Commun. 2017:8:14406. 
90. Kim E, Koo T, Park SW, Kim D, Kim K, Cho HY, Song DW, Lee KJ, Jung $\mathrm{MH}, \mathrm{Kim} \mathrm{S}$, et al. In vivo genome editing with a small Cas9 orthologue derived from Campylobacter jejuni. Nat Commun. 2017;8:14500.

91. Daboussi F, Leduc S, Marechal A, Dubois G, Guyot V, Perez-Michaut C, Amato A, Falciatore A, Juillerat A, Beurdeley M, et al. Genome engineering empowers the diatom Phaeodactylum tricornutum for biotechnology. Nat Commun. 2014;5:3831.

92. Pavlovic G, Erbs V, Andre P, Sylvie J, Eisenman B, Dreyer D, Lorentz R, Wattenhofer-Donze M, Birling MC, Herault Y. Generation of targeted overexpressing models by CRISPR/Cas9 and need of careful validation of your knock-in line obtained by nuclease genome editing. Transgenic Res. 2016;25(2):254-5

93. Li J, Shou J, Guo Y, Tang Y, Wu Y, Jia Z, Zhai Y, Chen Z, Xu Q, Wu Q. Efficient inversions and duplications of mammalian regulatory DNA elements and gene clusters by CRISPR/Cas9. J Mol Cell Biol. 2015;7(4):284-98.

94. Kuscu C, Arslan S, Singh R, Thorpe J, Adli M. Genome-wide analysis reveals characteristics of off-target sites bound by the Cas 9 endonuclease. Nat Biotechnol. 2014;32(7):677-83.

95. Zetsche B, Gootenberg JS, Abudayyeh OO, Slaymaker IM, Makarova KS, Essletzbichler P, Volz SE, Joung J, van der Oost J, Regev A, et al. Cpf1 Is a single RNA-guided endonuclease of a class 2 CRISPR-Cas system. Cell. 2015;163(3):759-71

96. Mathur J, Koncz C. PEG-mediated protoplast transformation with naked DNA. Methods Mol Biol. 1998;82:267-76.

97. Wu JZ, Liu Q, Geng XS, Li KM, Luo LJ, Liu JP. Highly efficient mesophyll protoplast isolation and PEG-mediated transient gene expression for rapid and large-scale gene characterization in cassava (Manihot esculenta Crantz). BMC Biotechnol. 2017;17(1):29.

98. Ariyoshi M, Vassylyev DG, Iwasaki H, Nakamura H, Shinagawa H, Morikawa K. Atomic structure of the RuvC resolvase: a holliday junctionspecific endonuclease from E. coli. Cell. 1994;78(6):1063-72.

99. Xu SY, Gupta YK. Natural zinc ribbon HNH endonucleases and engineered zinc finger nicking endonuclease. Nucleic Acids Res. 2013;41(1):378-90.

100. Nishimasu H, Ran FA, Hsu PD, Konermann S, Shehata SI, Dohmae N, Ishitani R, Zhang F, Nureki O. Crystal structure of Cas9 in complex with guide RNA and target DNA. Cell. 2014;156(5):935-49.

101. Fauser F, Schiml S, Puchta H. Both CRISPR/Cas-based nucleases and nickases can be used efficiently for genome engineering in Arabidopsis thaliana. Plant J. 2014;79(2):348-59.

102. Bikard D, Jiang W, Samai P, Hochschild A, Zhang F, Marraffini LA Programmable repression and activation of bacterial gene expression using an engineered CRISPR-Cas system. Nucleic Acids Res. 2013:41(15):7429-37.

103. Tong Y, Charusanti P, Zhang L, Weber T, Lee SY. CRISPR-Cas9 based engineering of Actinomycetal genomes. ACS Synth Biol. 2015;4(9):1020-9.

104. Kao PH, Ng IS. CRISPRi mediated phosphoenolpyruvate carboxylase regulation to enhance the production of lipid in Chlamydomonas reinhardtii. Bioresour Technol. 2017;245(Pt B):1527-37.

105. East-Seletsky A, O'Connell MR, Knight SC, Burstein D, Cate JH, Tjian R, Doudna JA. Two distinct RNase activities of CRISPR-C2C2 enable guideRNA processing and RNA detection. Nature. 2016;538(7624):270-3.

106. Hammond SM, Bernstein E, Beach D, Hannon GJ. An RNA-directed nuclease mediates post-transcriptional gene silencing in Drosophila cells. Nature. 2000;404(6775):293-6.

107. Hammond SM, Boettcher S, Caudy AA, Kobayashi R, Hannon GJ. Argonaute2, a link between genetic and biochemical analyses of RNAi. Science. 2001;293(5532):1146-50.

108. Tomari Y, Zamore PD. Perspective: machines for RNAi. Genes Dev. 2005;19(5):517-29.

109. Liu L, Li X, Wang J, Wang M, Chen P, Yin M, Li J, Sheng G, Wang Y. Two distant catalytic sites are responsible for C2C2 RNase activities. Cell. 2017;168(1-2):121.e112-134.e112

110. Cerutti H, Ma X, Msanne J, Repas T. RNA-mediated silencing in algae: biological roles and tools for analysis of gene function. Eukaryot Cell. 2011;10(9):1164-72

111. Jiang W, Brueggeman AJ, Horken KM, Plucinak TM, Weeks DP. Successful transient expression of Cas9 and single guide RNA genes in Chlamydomonas reinhardtii. Eukaryot Cell. 2014;13(11):1465-9.
112. Baek K, Kim DH, Jeong J, Sim SJ, Melis A, Kim JS, Jin E, Bae S. DNA-free two-gene knockout in Chlamydomonas reinhardtii via CRISPR-Cas9 ribonucleoproteins. Sci Rep. 2016;6:30620.

113. Wang $Q$, Lu Y, Xin Y, Wei L, Huang S, Xu J. Genome editing of model oleaginous microalgae Nannochloropsis spp. by CRISPR/Cas9. Plant J. 2016;88(6):1071-81

114. Ajjawi I, Verruto J, Aqui M, Soriaga LB, Coppersmith J, Kwok K, Peach L, Orchard E, Kalb R, Xu W, et al. Lipid production in Nannochloropsis gaditana is doubled by decreasing expression of a single transcriptional regulator. Nat Biotechnol. 2017;35(7):647-52.

115. Mable BK, Otto SP. The evolution of life cycles with haploid and diploid phases. BioEssays. 1998;20(6):453-62.

116. Kilian O, Benemann CS, Niyogi KK, Vick B. High-efficiency homologous recombination in the oil-producing alga Nannochloropsis sp. Proc Natl Acad Sci USA. 2011;108(52):21265-9.

117. Hirakawa Y, Ishida K. Polyploidy of endosymbiotically derived genomes in complex algae. Genome Biol Evol. 2014;6(4):974-80.

118. Song Y, Xu Y, Deng J, Chen M, Lu Y, Wang Y, Yao H, Zhou L, Liu Z, Lai L, et al. CRISPR/Cas9-mediated mutation of tyrosinase (Tyr) 3' UTR induce graying in rabbit. Sci Rep. 2017;7(1):1569.

119. Seth K. Harish: current status of potential applications of repurposed Cas9 for structural and functional genomics of plants. Biochem Biophys Res Commun. 2016;480(4):499-507.

120. Dong, Guo M, Wang S, Zhu Y, Wang S, Xiong Z, Yang J, Xu Z, Huang Z. Structural basis of CRISPR-SpyCas9 inhibition by an anti-CRISPR protein. Nature. 2017:546:436-9.

121. Rauch BJ, Silvis MR, Hultquist JF, Waters CS, McGregor MJ, Krogan NJ, Bondy-Denomy J. Inhibition of CRISPR-Cas9 with bacteriophage proteins. Cell. 2017;168(1-2):150.e110-158.e110.

122. Caliando BJ, Voigt CA. Targeted DNA degradation using a CRISPR device stably carried in the host genome. Nat Commun. 2015;6:6989.

123. Lander ES. The heroes of CRISPR. Cell. 2016;164(1-2):18-28.

124. Qi LS, Larson MH, Gilbert LA, Doudna JA, Weissman JS, Arkin AP, Lim WA. Repurposing CRISPR as an RNA-guided platform for sequence-specific control of gene expression. Cell. 2013;152(5):1173-83.

125. Gilbert LA, Larson MH, Morsut L, Liu Z, Brar GA, Torres SE, Stern-Ginossar N, Brandman O, Whitehead EH, Doudna JA, et al. CRISPR-mediated modular RNA-guided regulation of transcription in eukaryotes. Cell. 2013;154(2):442-51

126. Farzadfard F, Perli SD, Lu TK. Tunable and multifunctional eukaryotic transcription factors based on CRISPR/Cas. ACS Synth Biol. 2013;2(10):604-13.

127. Perez-Pinera P, Kocak DD, Vockley CM, Adler AF, Kabadi AM, Polstein LR, Thakore PI, Glass KA, Ousterout DG, Leong KW, et al. RNA-guided gene activation by CRISPR-Cas9-based transcription factors. Nat Methods. 2013;10(10):973-6.

128. Tanenbaum ME, Gilbert LA, Qi LS, Weissman JS, Vale RD. A protein-tagging system for signal amplification in gene expression and fluorescence imaging. Cell. 2014;159(3):635-46.

129. Chavez A, Scheiman J, Vora S, Pruitt BW, Tuttle M, lyer EPR, Lin S, Kiani S, Guzman CD, Wiegand DJ, et al. Highly efficient Cas9-mediated transcriptional programming. Nat Methods. 2015;12(4):326-8.

130. Konermann S, Brigham MD, Trevino AE, Joung J, Abudayyeh $\mathrm{OO}$, Barcena C, Hsu PD, Habib N, Gootenberg JS, Nishimasu H, et al. Genome-scale transcriptional activation by an engineered CRISPR-Cas9 complex. Nature. 2015;517(7536):583-8.

131. Mali P, Aach J, Stranges PB, Esvelt KM, Moosburner M, Kosuri S, Yang L, Church GM. CAS9 transcriptional activators for target specificity screening and paired nickases for cooperative genome engineering. Nat Biotechnol. 2013:31(9):833-8.

132. La Russa MF, Qi LS. The new state of the art: Cas9 for gene activation and repression. Mol Cell Biol. 2015;35(22):3800-9.

133. Gilbert LA, Horlbeck MA, Adamson B, Villalta JE, Chen Y, Whitehead EH, Guimaraes C, Panning B, Ploegh HL, Bassik MC, et al. Genome-scale CRISPR-mediated control of gene repression and activation. Cell. 2014:159(3):647-61.

134. Kearns NA, Pham H, Tabak B, Genga RM, Silverstein NJ, Garber M, Maehr R. Functional annotation of native enhancers with a Cas9-histone demethylase fusion. Nat Methods. 2015;12(5):401-3.

135. Hilton IB, D'Ippolito AM, Vockley CM, Thakore PI, Crawford GE, Reddy TE, Gersbach CA. Epigenome editing by a CRISPR-Cas9-based 
acetyltransferase activates genes from promoters and enhancers. Nat Biotechnol. 2015;33(5):510-7.

136. Thakore PI, D'Ippolito AM, Song L, Safi A, Shivakumar NK, Kabadi AM, Reddy TE, Crawford GE, Gersbach CA. Highly specific epigenome editing by CRISPR-Cas9 repressors for silencing of distal regulatory elements. Nat Methods. 2015;12(12):1143-9.

137. Keung AJ, Bashor CJ, Kiriakov S, Collins JJ, Khalii AS. Using targeted chromatin regulators to engineer combinatorial and spatial transcriptional regulation. Cell. 2014;158(1):110-20.

138. Komor Alexis C, Badran Ahmed H, Liu David R. CRISPR-based technologies for the manipulation of eukaryotic genomes. Cell. 2016;168(1-2):20-36.

139. Auer TO, Del Bene F. CRISPR/Cas9 and TALEN-mediated knock-in approaches in zebrafish. Methods. 2014;69(2):142-50.

140. Zu Y, Tong X, Wang Z, Liu D, Pan R, Li Z, Hu Y, Luo Z, Huang P, Wu Q, et al. TALEN-mediated precise genome modification by homologous recombination in zebrafish. Nat Methods. 2013;10(4):329-31.

141. Bedell VM, Wang Y, Campbell JM, Poshusta TL, Starker CG, Krug RG 2nd, Tan W, Penheiter SG, Ma AC, Leung AY, et al. In vivo genome editing using a high-efficiency TALEN system. Nature. 2012;491 (7422):114-8.

142. Auer TO, Duroure K, De Cian A, Concordet JP, Del Bene F. Highly efficient CRISPR/Cas9-mediated knock-in in zebrafish by homology-independent DNA repair. Genome Res. 2014;24(1):142-53.

143. Matzke AJ, Matzke MA. Position effects and epigenetic silencing of plant transgenes. Curr Opin Plant Biol. 1998;1(2):142-8.

144. Singh J, Freeling M, Lisch D. A position effect on the heritability of epigenetic silencing. PLoS Genet. 2008;4(10):e1000216.

145. Jeong B-r, Wu-Scharf D, Zhang C, Cerutti H. Suppressors of transcriptional transgenic silencing in Chlamydomonas are sensitive to DNAdamaging agents and reactivate transposable elements. Proc Natl Acad Sci USA. 2002;99(2):1076-81.

146. Zhang C, Wu-Scharf D, Jeong B-r, Cerutti H. A WD40-repeat containing protein, similar to a fungal co-repressor, is required for transcriptional gene silencing in Chlamydomonas. Plant J. 2002;31(1):25-36.

147. Casas-Mollano JA, Jeong B-r, Xu J, Moriyama H, Cerutti H. The MUT9p kinase phosphorylates histone $\mathrm{H} 3$ threonine 3 and is necessary for heritable epigenetic silencing in Chlamydomonas. Proc Natl Acad Sci USA. 2008;105(17):6486-91.

148. Wu H, Wang Y, Zhang Y, Yang M, LV J, Liu J, Zhang Y. TALE nickasemediated SP110 knockin endows cattle with increased resistance to tuberculosis. Proc Natl Acad Sci USA. 2015;112(13):E1530-9.

149. Tuggle CK, Waters WR. Tuberculosis-resistant transgenic cattle. Proc Natl Acad Sci USA. 2015;112(13):3854-5.

150. Pan K, Qin J, Li S, Dai W, Zhu B, Jin Y, Yu W, Yang G, Li D. Nuclear monoploidy and asexual propagation of Nannochloropsis oceanica (Eustigmatophyceae) as revealed by its genome sequence. J Phycol. 2011;47(6):1425-32.

151. Arnold AA, Genard B, Zito F, Tremblay R, Warschawski DE, Marcotte I. Identification of lipid and saccharide constituents of whole microalgal cells by ${ }^{13} \mathrm{C}$ solid-state NMR. Biochim Biophys Acta. 2015;1848(1 Pt B):369-77.

152. Bortesi L, Zhu C, Zischewski J, Perez L, Bassie L, Nadi R, Forni G, Lade SB, Soto $E$, Jin $X$, et al. Patterns of CRISPR/Cas 9 activity in plants, animals and microbes. Plant Biotechnol J. 2016;14(12):2203-16.

153. Kindle KL, Schnell RA, Fernandez E, Lefebvre PA. Stable nuclear transformation of Chlamydomonas using the Chlamydomonas gene for nitrate reductase. J Cell Biol. 1989;109(6):2589-601.

154. Mayfield SP, Kindle KL. Stable nuclear transformation of Chlamydomonas reinhardtii by using a Chlamydomonas reinhardtii gene as the selectable marker. P Natl Acad Sci USA. 1990;87(6):2087-91.

155. Ferris PJ. Localization of the nic-7, ac-29 and thi-10 genes within the mating-type locus of Chlamydomonas reinhardtii. Genetics. 1995;141(2):543-9.

156. Cerutti H, Johnson AM, Gillham NW, Boynton JE. A eubacterial gene conferring spectinomycin resistance on Chlamydomonas reinhardtii: integration into the nuclear genome and gene expression. Genetics. 1997;145(1):97-110

157. Sizova I, Fuhrmann M, Hegemann P. A Streptomyces rimosus aphVIII gene coding for a new type phosphotransferase provides stable antibiotic resistance to Chlamydomonas reinhardtii. Gene. 2001;277(1-2):221-9.
158. Berthold P, Schmitt R, Mages W. An engineered Streptomyces hygroscopicus aph 7 " gene mediates dominant resistance against hygromycin B in Chlamydomonas reinhardtii. Protist. 2002;153(4):401-12.

159. Kovar JL, Zhang J, Funke RP, Weeks DP. Molecular analysis of the acetolactate synthase gene of Chlamydomonas reinhardtii and development of a genetically engineered gene as a dominant selectable marker for genetic transformation. Plant J. 2002;29(1):109-17.

160. Chow KC, Tung WL. Electrotransformation of Chlorella vulgaris. Plant Cell Rep. 1999;18(9):778-80.

161. Niu YF, Zhang MH, Xie WH, Li JN, Gao YF, Yang WD, Liu JS, Li HY. A new inducible expression system in a transformed green alga. Chlorella vulgaris. Genet Mol Res. 2011;10(4):3427-34.

162. Liu J, Sun Z, Gerken H, Huang J, Jiang Y, Chen F. Genetic engineering of the green alga Chlorella zofingiensis: a modified norflurazon-resistant phytoene desaturase gene as a dominant selectable marker. Appl Microbiol Biotechnol. 2014;98(11):5069-79.

163. Zhang J, Hao Q, Bai L, Xu J, Yin W, Song L, Xu L, Guo X, Fan C, Chen Y, et al. Overexpression of the soybean transcription factor GmDof4 significantly enhances the lipid content of Chlorella ellipsoidea. Biotechnol Biofuels. 2014;7(1):128.

164. Apt KE, Kroth-Pancic PG, Grossman AR. Stable nuclear transformation of the diatom Phaeodactylum tricornutum. Mol Gen Genet. 1996;252(5):572-9.

165. Zaslavskaia LA, Lippmeier JC, Kroth PG, Grossman AR, Apt KE. Transformation of the diatom Phaeodactylum tricornutum (Bacillariophyceae) with a variety of selectable marker and reporter genes. J Phycol. 2000;36(2):379-86.

166. De Riso V, Raniello R, Maumus F, Rogato A, Bowler C, Falciatore A. Gene silencing in the marine diatom Phaeodacty/um tricornutum. Nucleic Acids Res. 2009;37(14):e96.

167. Hamilton ML, Haslam RP, Napier JA, Sayanova O. Metabolic engineering of Phaeodactylum tricornutum for the enhanced accumulation of omega-3 long chain polyunsaturated fatty acids. Metab Eng. 2014;22:3-9.

168. Radakovits R, Jinkerson RE, Fuerstenberg SI, Tae H, Settlage RE, Boore $J \mathrm{~L}$, Posewitz MC. Draft genome sequence and genetic transformation of the oleaginous alga Nannochloropsis gaditana. Nat Commun. 2013;4:686.

169. Kang NK, Choi GG, Kim EK, Shin SE, Jeon S, Park MS, Jeong KJ, Jeong BR, Chang YK, Yang JW, et al. Heterologous overexpression of sfCherry fluorescent protein in Nannochloropsis salina. Biotechnol Rep. 2015;8:10-5.

170. Geng DG, Han Y, Wang YQ, Wang P, Zhang LM, Li WB, Sun YR. Construction of a system for the stable expression of foreign genes in Dunaliella salina. Acta Bot Sin. 2004;46(3):342-6.

171. Sun Y, Yang Z, Gao X, Li Q, Zhang Q, Xu Z. Expression of foreign genes in Dunaliella by electroporation. Mol Biotechnol. 2005;30(3):185-92.

172. Sun Y, Gao X, Li Q, Zhang Q, Xu Z. Functional complementation of a nitrate reductase defective mutant of a green alga Dunaliella viridis by introducing the nitrate reductase gene. Gene. 2006;377:140-9.

173. Sun G, Zhang X, Sui Z, Mao Y. Inhibition of $p d s$ gene expression via the RNA interference approach in Dunaliella salina (Chlorophyta). Mar Biotechnol. 2008;10(3):219-26.

174. Talebi AF, Tohidfar M, Bagheri A, Lyon SR, Salehi-Ashtiani K, Tabatabaei M. Manipulation of carbon flux into fatty acid biosynthesis pathway in Dunaliella salina using AcCD and ME genes to enhance lipid content and to improve produced biodiesel quality. Biofuel Res J. 2014;1(3):91-7.

175. Steinbrenner J, Sandmann G. Transformation of the green alga Haematococcus pluvialis with a phytoene desaturase for accelerated astaxanthin biosynthesis. Appl Environ Microbiol. 2006;72(12):7477-84.

176. Kathiresan S, Chandrashekar A, Ravishankar GA, Sarada R. Agrobacterium-mediated transformation in the green alga Haematococcus pluvialis (Chlorophyceae, Volvocales). J Phycol. 2009;45(3):642-9.

177. Kathiresan S, Chandrashekar A, Ravishankar GA, Sarada R. Regulation of astaxanthin and its intermediates through cloning and genetic transformation of beta-carotene ketolase in Haematococcus pluvialis. J Biotechnol. 2015;196-197:33-41.

178. Zhou J, Wang J, Shen B, Chen L, Su Y, Yang J, Zhang W, Tian X, Huang X. Dual sgRNAs facilitate CRISPR/Cas9-mediated mouse genome targeting. FEBS J. 2014;281 (7):1717-25. 
179. Xu K, Chen G, Li X, Wu X, Chang Z, Xu J, Zhu Y, Yin P, Liang X, Dong L. MFN2 suppresses cancer progression through inhibition of mTORC2/ Akt signaling. Sci Rep. 2017;7:41718.

180. Chen S, Lee B, Lee AY, Modzelewski AJ, He L. Highly efficient mouse genome editing by CRISPR ribonucleoprotein electroporation of Zygotes. J Biol Chem. 2016;291(28):14457-67.

181. Zhang D, Wang J, Zhou C, Xiao W. Zebrafish akt2 is essential for survival, growth, bone development, and glucose homeostasis. Mech Dev. 2017;143:42-52.

182. Jiang W, Yang B, Weeks DP. Efficient CRISPR/Cas9-mediated gene editing in Arabidopsis thaliana and inheritance of modified genes in the T2 and T3 generations. PLoS ONE. 2014;9(6):e99225.

183. Jiang WZ, Henry IM, Lynagh PG, Comai L, Cahoon EB, Weeks DP. Significant enhancement of fatty acid composition in seeds of the allohexaploid, Camelina sativa, using CRISPR/Cas9 gene editing. Plant Biotechnol J. 2017;15(5):648-57.

184. Svitashev S, Schwartz C, Lenderts B, Young JK, Mark Cigan A. Genome editing in maize directed by CRISPR-Cas9 ribonucleoprotein complexes. Nat Commun. 2016;7:13274.
185. Liang Z, Chen K, Li T, Zhang Y, Wang Y, Zhao Q, Liu J, Zhang H, Liu C, Ran Y, et al. Efficient DNA-free genome editing of bread wheat using CRISPR/Cas9 ribonucleoprotein complexes. Nat Commun. 2017:8:14261.

186. Wendt KE, Ungerer J, Cobb RE, Zhao H, Pakrasi HB. CRISPR/Cas9 mediated targeted mutagenesis of the fast growing cyanobacterium Synechococcus elongatus UTEX 2973. Microb Cell Fact. 2016;15(1):115.

187. Li H, Shen CR, Huang CH, Sung LY, Wu MY, Hu YC. CRISPR-Cas9 for the genome engineering of cyanobacteria and succinate production. Metab Eng. 2016;38:293-302.

188. Ungerer J, Pakrasi HB. Cpf1 Is a versatile tool for CRISPR genome editing across diverse species of cyanobacteria. Sci Rep. 2016;6:39681.

189. Nymark M, Sharma AK, Sparstad T, Bones AM, Winge P. A CRISPR/Cas9 system adapted for gene editing in marine algae. Sci Rep. 2016;6:24951.

\section{Submit your next manuscript to BioMed Central and we will help you at every step:}

- We accept pre-submission inquiries

- Our selector tool helps you to find the most relevant journal

- We provide round the clock customer support

- Convenient online submission

- Thorough peer review

- Inclusion in PubMed and all major indexing services

- Maximum visibility for your research

Submit your manuscript at www.biomedcentral com/submit 